\title{
A Compliance-Based Theory of International Law
}

\author{
Andrew T. Guzman $\dagger$
}

\section{TABLE OF CONTENTS}

Introduction.

I. Existing Theories of International Law ........................................ 1830

A. TraditionaI LegaI Theories................................................... 1830

B. International Relations Theories............................................ 1836

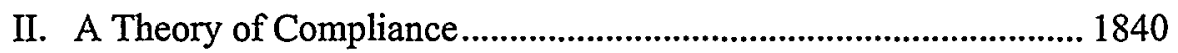

A. A Theory of the Irrelevance of International Law .................... 1841

B. A Theory of the Relevance of International Law ..................... 1844

C. An Application of the Model: Bilateral Investment Treaties... 1851

D. Dynamic Issues ...................................................................... 1853

E. The Level of Commitment....................................................... 1854

F. International Law and Coordination ....................................... 1857

III. Violation and Compliance......................................................... 1860

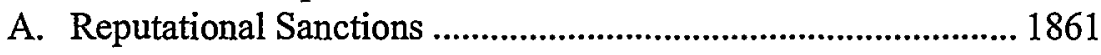

B. Direct Sanctions .................................................................... 1865

C. When Will Sanctions Work Best? ............................................. 1868

D. Acceptance of Sanctions........................................................ 1871

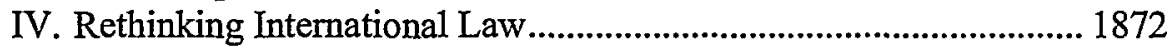

A. Rethinking Treaties.............................................................. 1873

B. Rethinking Customary International Law................................ 1874

C. Rethinking International Law ................................................ 1878

D. The Problem of Large Stakes................................................ 1883

Copyright $(2002$ California Law Review, Inc. California Law Review, Inc. (CLR) is a California nonprofit corporation. CLR and the authors are solely responsible for the content of their publications

i Assistant Professor of Law, School of Law, University of California, Berkeley (Boalt Hall). I owe thanks to David Caron, Stephen Choi, Jack Goldsmith, Benedict Kingsbury, Chris Kutz, Eric Posner, Kal Raustiala, Beth Simmons, Anne-Marie Slaughter, Paul Stephan, John Yoo, participants at faculty workshops at Boalt Hall, Duke University School of Law, Vanderbilt University Law School, University of Virginia School of Law, the Canadian Law and Economics Association 2001 Annual Meeting, the 2001 Southem California International Law Professors Dinner at Loyola Law School, Los Angeles, and the Boalt Hall International Law and Politics Workshop for helpfuI discussions and comments. Special thanks to Jeannie Sears and Nicholas James. Ryan Waterman provided excellent research assistance. I am grateful to the John M. Olin Foundation for financial assistance. Contact: guzman@law.berkeley.edu. 
[Vol. 90:1823

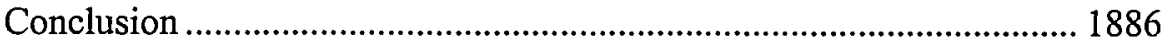




\title{
A Compliance-Based Theory of International Law
}

\author{
Andrew T. Guzman
}

This Article examines international law from the perspective of compliance. It puts forward a theory of international law in which compliance comes about in a model of rational, self-interested states. International law can affect state behavior because states are concerned about the reputational and direct sanctions that follow its violation. The model allows us to consider international law in a new light. Most strikingly, one is forced to reconsider two of the most fundamental doctrinal points in the field-the definitions of customary international law ("CIL") and of international law itself. A reputational model of compliance makes it clear that CIL affects the behavior of a state because other states believe that the first state has a commitment that it must honor. A failure to honor that commitment hurts a state's reputation because it signals that it is prepared to breach its obligations. This implies a definition that turns on the existence of an obligation in the eyes of other states rather than the conventional requirements of state practice and a sense of legal obligation felt by the breaching state.

Classical definitions of international law look to two primary sources of law-treaties and CIL. A reputational theory, however, would label as international law any promise that materially alters state incentives. This includes agreements that fall short of the traditional definition, including what is often referred to as "soft law." The Article points out that there is no way to categorize treaties and CIL as "law" without also including soft law. Agreements such as ministerial accords or memoranda of understanding represent commitments by a state which, if breached, will have a reputational impact. For this reason, these soft-law agreements should be included in the definition of international law.

The Article also calls for a refocusing of international-law scholarship. Because international law works through reputational and direct sanctions, we must recognize that these sanctions have limited force. As a result, international law is more likely to have an impact on events when the stakes are relatively modest. The implication is that many of the topics that receive the most attention in international law-the laws of war, territorial limits, arms agreements, and so on-are unlikely to be affected by international law. On the other hand, issues such as international economic matters, environmental issues, and so on, can more easily be 
affected by international law. This suggests that the international-law academy should focus greater attention on the latter subjects and less on the former.

\section{INTRODUCTION}

Legal scholarship lacks a satisfactory theory of why and when states comply with international law. Most scholars and practitioners of international law believe that international law matters, by which they mean it affects the behavior of states. ${ }^{1}$ Furthermore, this view coincides with empirical evidence on the relevance of international law. ${ }^{2}$ Nevertheless, the theories advanced by legal scholars are considered flawed because they are difficult to reconcile with modern international relations theory, rely heavily on axiomatic claims about national behavior, and lack a coherent theory of compliance with international law. ${ }^{3}$ The absence of a coherent coinpliance theory may explain why most conventional international law scholarship assumes that there is compliance but fails to ask why. ${ }^{4}$ Yet, the failure to understand the compliance decision is troubling because compliance is one of the most central questions in international law. Indeed, the absence of an explanation for why states obey international law in some instances but not others threatens to undermine the very foundations of the discipline.

Without an understanding of the counection between international law and state actions, scholars cannot hope to provide useful policy advice with respect to international law. Inproving the functioning of the international legal system and developing a workable theory of international legal and regulatory cooperation also require a coherent theory of compliance with international law. At present, the best theories relevant to international law and coinpliance come not from legal scholarship, but from international relations scholarship. ${ }^{5}$ The scholars developing these theories, however, are

1. See Louls Henkin, How Nations Behave: Law and Foreign Policy $46-48$ (1979); Abram H. Chayes \& Antonia Chayes, On Compliance, 47 INT'L ORg. 175, 176 (1993).

2. See Beth A. Simmons, Money and the Law: Why Comply with the Public International Law of Money?, 25 YALE J. INT'L L. 323 (2000).

3. See Jeffrey L. Dunoff \& Joel P. Trachtman, Economic Analysis of International Law, 24 YALE J. INT'L L. 1, 28 (1999) ("Past efforts to identify an underlying structure for the law of treaties have proven unsatisfactory."); Harold Hongju Koh, Why Do Nations Obey International Law?, 106 YAle L.J. 2599 (1997); John K. Setear, An Iterative Perspective on Treaties: A Synthesis of International Relations Theory and International Law, HARV. INT'L L.J. 139, 147 (1996) (criticizing two theoretical justifications for the law of treaties).

4. See, e.g., Abram Chayes \& Antonia Handler Chayes, The New SOVEREIGNTY: COMPLIANCE WITH INTERNATIONAL Regulatory AGREemenTs 3 (1995) ("[F]oreign policy practitioners operate on the assumption of a general propensity of states to comply with international obligations.").

5. The most prominent interdisciplinary articles include Kenneth W. Abbott, Modern International Relations Theory: A Prospectus for International Lawyers, 14 YALE J. INT'L L. 335 (1989) [hereinafter Abbott, Prospectus]; Kenneth W. Abbott, International Relations Theory, 
often skeptical of international law's relevance to the international system, ${ }^{6}$ or ignore international law altogether. ${ }^{7}$

This Article draws on international relations theory to develop a better theory of compliance with international law. Unlike traditional international law scholarship, the theory developed here explains compliance using a model of rational, self-interested states. It argues that compliance occurs due to state concern about both reputational and direct sanctions triggered by violations of the law. This theory explains not only why nations comply, but also why and when they violate international law. Furthermore, this Article responds to the argument that international law is inerely epiphenomenal by constructing a model of rational, self-interested states in which international law does, in fact, matter. ${ }^{8}$

Further, the nodel raises fundamental questions about the manner in which scholars currently study international law. By taking the question of compliance seriously, we gain a new perspective on international law and are forced to question some of its central tenets. Though the analysis inpacts other aspects of international law, this Article discusses four primary implications of the theory.

International Law, and the Regime Governing Atrocities in Internal Conflicts, 93 AM. J. INT'L L. 361 (1999) [hereinafter Abbott, Atrocities]; Dunoff \& Trachtman, supra note 3; Jack L. Goldsmith \& Eric A. Posner, A Theory of Customary International Law, 66 U. CHI. L. REV. 1113 (1999); Koh, supra note 3; Kal Raustiala \& Anne-Marie Slaughter, International Law, International Relations and Compliance, in The HandbooK of Internatronal Relations 28 (Walter Carlsnaes et al. eds., 2002); John K. Setear, Responses to Breach of a Treaty and Rationalist International Relations Theory: The Rules of Release and Remediation in the Law of Treaties and the Law of State Responsibility, 83 VA. L. REv. 1 (1997); Setear, supra note 3; Anne-Marie Slaughter, International Law and International Relations, 285 RECUEIL DES Cours 9 (2000); Anne-Marie Slaughter et al., International Law and International Relations Theory: A New Generation of Interdisciplinary Scholarship, 92 AN. J. INT'L L. 367 (1998); Anne-Marie Slaughter Burley, International Law and International Relations Theory: A Dual Agenda, 87 AM. J. INT'L L. 205 (1993); Edwin M. Smith, Understanding Dynamic Obligations: Arms Control Agreements, 64 S. CAL. L. REv. 1549 (1991). In addition, a recent issue of International Organization (Summer 2000) is devoted to an international relations approach to questions of international law.

6. See George W. Downs et al., Is the Good News About Compliance Good News About Cooperation?, 50 INT'L ORG. 379 (1996); Simmons, supra note 2, at 323-24 ("[L]egal scholars and practitioners believe that the rules at the center of their analysis do indeed matter.... Scholars of international relations ... have been far more skeptical.").

7. See Michael Byers, Custom, Power and the Power of Rules: International RELATIONS AND Customary INTERNational LAW 8 (1999) ("Intemational relations scholars have traditionally had little time for such questions. Instead, they have regarded international law as something of an epiphenomenon, with rules of international law being dependent on power, subject to short-term alteration by power-applying States, and therefore of little relevance to how States actually behave.").

8. The model has the merit of being consistent with both conventional wisdom and empirical evidence showing that international law matters, as well as the observation that the law is sometimes violated. See, e.g., Simmons, supra note 2 (presenting empirical evidence that international law impacts government behavior). 
First, the theory suggests that the current understanding of customary international law ("CIL") is inadequate. ${ }^{9}$ The existing definition of CIL has been subject to a great deal of criticism, in part because of its failure to connect compliance with international law. Some have gone so far as to suggest that no such law exists. ${ }^{10}$ Rather than attempting to salvage the traditional definition, this Article proposes a new one that focuses on whether a rule of CIL affects behavior. The Article demonstrates that the traditional requirements of widespread state practice and a sense of legal obligation do not contribute to a useful understanding of CIL. By studying CIL within a reputational model, and with a focus on compliance, it is possible to achieve a deeper understanding of that form of international law.

Second, the Article challenges our understanding of international law itself. ${ }^{11}$ Considering international law from the perspective of compliance makes clear that the classical definition of international law is underinclusive and should be broadened to include not only treaties and CIL, but also agreements such as ministerial accords, memoranda of understanding, and so on. ${ }^{12}$ Like treaties and CIL, these instruments affect the incentives of states and, therefore, should be considered international law. Including them in the definition allows us to study the full range of international obligations within a single theoretical framework and, unlike traditional theories, explains both the existence and popularity of such agreements. This approach resolves the existing debate regarding "soft law" by pointing out that it should not be considered different from other forms of international law. Rather, it should be recognized as part of a spectrum of commitment along which states choose to locate their promises.

Third, this Article demonstrates that international law will most likely affect outcomes in situations with many repeated interactions, each with relatively small stakes. ${ }^{13}$ Although this claim is not new, it leads to the conclusion that the topics that have traditionally held center stage in international law - the laws of war, neutrality, arms control, and so on-are precisely those in which international law is least likely to be relevant. This conclusion has two lessons for international law scholarship. First, international law scholarship may be unduly focused on these topics. It may have a greater impact on human well being when it focuses on areas in which international law can alter outcomes more reliably, including economic,

9. CIL represents one of the two commonly cited sources of international law, the other being treaties. See BYERS, supra note 7, at I66. A rule is considered to be a rule of CIL if it satisfies the requirements of consistent and general practice among states and a belief among states that their practice is in accordance with the law. See Statute of the International Court of Justice, June 26, 1945, art. 38(1)(b).

10. See infra Part IV.B.

11. See infra Part IV.C.

12. See infra Part IV.C.1.

13. See infra Part IV.D. 
environmental, and labor issues. Second, and somewhat subtler, the study of these issues and the design of international institutions should proceed with an understanding of the limits of international law. International law can play a role in encouraging cooperation, but it can only do so if its obligations are structured to reduce the importance of each compliance decision. For example, an arms treaty by itself may have little success, but a treaty that provides for periodic inspections by a neutral third party may stand a greater chance of achieving the goal of arms control.

Fourth, this Article shows that sanctions for violations of international law are generally not optimal. ${ }^{14}$ Because sanctions consist primarily of econornic punishment and reputational losses, they are often too weak to achieve optimal compliance. ${ }^{15}$ Under certain circumstances, however, states can be given better incentives. In particular, states can be imduced to voluntarily submit to dispute-resolution procedures and to accept sanctions when a failure to accept a sanction leads to an even greater loss. Understanding how to encourage participation in dispute-resolution procedures $\mathrm{m}$ turn sheds light on the role of international organizations. Because international organizations can coordinate international interactions to increase the likelihood that states will submit to the authority of dispute-resolution bodies, such organizations have an important role. This Article discusses both how international interactions can be structured and the role of international organizations in affecting and sanctioning state behavior.

This Article begins in Part 1 by discussing the most prominent theories of international law from both traditional legal scholarship and international relations perspectives. Part II presents the theory of compliance within a framework of rational and self-interested states. ${ }^{16}$ Part III presents a detailed discussion of how both reputational and direct sanctions affect states and how their magnitude changes depending on the circuinstances of the violation. Part IV develops several of the theory's most striking

14. See infra Part III.D.

15. See Chayes \& ChAYEs, supra note 4, at 29-33. Even when they are effective, direct punitive sanctions such as embargoes may at times be too harsh and fail to generate optimal compliance.

16. Any theory of compliance must come to terms with the fact that international law, however one defines that term, has virtually no enforcement mechanism. See Thomas M. Franck, Legitimacy in the International System, 82 AM. J. INT'L L. 705, 707 (1988) ("Why should rules, unsupported by an effective structure of coercion comparable to a national police force, nevertheless elicit so much compliance, even against perceived self-interest, on the part of sovereign states?'). When a state violates international law, there are few formal procedures through which other countries can invoke sanctions. See Chayes \& Chayes, supra note 4, at 29-108 (discussing the weakness of punitive sanctions for violation of intemational law). That is not to say, however, that the violation of intemational law is without cost. Two costs of central importance will be the focus of this Article. First, following a country's breach of an interuational obligation, other states may choose to impose some form of sanction. This may range from criticizing the offending state to imposing economic or military sanctions. The second cost of violating an international obligation is reputational. If a country violates international law, other states may refuse to enter into future agreements, demand greater concessions when entering into such agreements, or lose faith in the strength of existing agreements. 
implications, explaining: (1) how it affects our understanding of treaties and ClL, and (2) why scholars should expand the definition of international law. Finally, it argues the fact that international law is unlikely to affect some of the topics traditionally of interest to international legal scholars and calls for a refocusing of scholarship on other areas where international law can have a greater impact.

\section{I}

\section{EXISTING THEORIES OF INTERNATIONAL LAW}

Compliance is central to international law's role in regulating the interaction of nations. Absent an incentive toward compliance, resources devoted to the creation and maintenance of international legal structures are wasted, and the study of international law is a futile endeavor. Despite the fundamental importance of the compliance question, however, the legal academy has failed to develop a satisfactory theory to explain it. This Part presents the most prominent attempts in the international law literature to explain compliance. It also presents theories from international relations that have filtered into the international law literature, including the institutionalist theory upon which this Article builds. ${ }^{17}$

\section{A. Traditional Legal Theories ${ }^{\prime 8}$}

\section{The Managerial Model}

Chayes and Chayes have provided the most satisfying of the traditional legal theories of international law and compliance. ${ }^{19}$ They argue that the "enforcement model" of compliance, in which compliance is achieved through coercive mechanisms such as sanctions, should be replaced with a "managerial model," which relies primarily on "a cooperative, problemsolving approach." ${ }^{20}$ Chayes and Chayes claim that the general propensity of states to comply with international law is the product of three factors. First, compliance avoids the need to recalculate the costs and benefits of a decision, saving transaction costs for complying states and generating an efficiency-based rationale for compliance..$^{21}$ Second, they argue that treaties are consent-based instruments that serve the interests of the participating states. ${ }^{22}$ Finally, they contend that a general norm of compliance furthers

17. For a discussion of the compliance literature that addresses both the legal and political science debate, see Raustiala \& Slaughter, supra note 5.

18. For an account of "ancient and primitive" international law, which predates the traditional views described hercin, see Koh, supra note 3, at 2604-06.

19. See Chayes \& Chayes, supra note 4.

20. Id. at 3.

21. See id. at 4.

22. See id. at 7. Chayes and Chayes note: 
state compliance in any particular instance. ${ }^{23}$ Although the managerial model presents a thoughtful and useful account of a certain class of treaties, it fails to describe many other types of international agreements. Specifically, it provides a satisfying account of agreements designed to resolve coordination problems, but it does not explaim how international law works in other situations.

In the case of coordination problems, once the parties have agreed on a certain set of behaviors, neither party has an incentive to deviate from the agreement, and compliance is the expected outcome even in the absence of enforcement. Because there is no incentive to cheat, there is no need to focus on enforcement. Resources are better directed at managerial issues, including transparency, ${ }^{24}$ dispute settlement, ${ }^{25}$ and capacity building, ${ }^{26}$ which all assist coordination efforts. Thus, at least in the narrow class of international agreements that involve coordination games, the managerial model successfully explains state compliance with international law.

When considering the use of international law beyond coordination games, however, the managerial model is less useful. To see why this is so, consider each of the three factors said to generate compliance. ${ }^{27}$ First, the managerial model focuses on transaction costs savcd through compliance with international law. Although states save some costs through a rule of compliance, these costs are not likely to be large and, in any event, there are many other strategies that can lead to similar cost savings. A better strategy from the state's perspective would be to make its compliance decisions based on whatever information it has without any presumption in favor of or against compliance. This would maximize the probability of making the appropriate choice while avoiding transaction costs. ${ }^{28}$

The second explanation for compliance is the consent-based theory discussed in Part I.A.2. As is shown im that Section, the consent theory

[I]f the agreement is well designed-sensible, comprehensible, and with a practical eye to probable patterns of conduct and interaction-compliance problems and enforcement issues are likely to be manageable. If issues of noncompliance and enforcement are endemic, the real problem is likely to be that the negotiating process did not succeed in incorporating a broad enough range of the parties interests.

Id. at 7 .

23. See id. at 8 ("The existence of legal obligation, for most actors in most situations, translates into a presumption of compliance, in the absence of strong countervailing circumstances. So it is with states... The norm [of compliance] is itself a 'reason for action' and thus becomes an independent basis for conforming behavior.").

24. See id. at 135-53.

25. See id. at 201-25.

26. See id. at 197-201.

27. See supra notes 20-23 and accompanying text.

28. Other strategies would be better still. The best strategy is to invest in information gathering until the marginal cost of additional information equals the information's marginal benefit in terms of its effect on the probability of making the correct choice and the cost of a mistake. Once a state gathers the optimal amount of information, it could base the decision on that information without a presumption in favor of compliance. 
cannot explain why the existence of an international legal obligation would influence state behavior. ${ }^{29}$

Finally, Chayes and Chayes argue that a compliance norm causes decision-makers to comply not out of fear of sanctions, but rather because the norm itself generates compliance pull. The claim that a norm exists in favor of compliance and that such a norm improves compliance, however, is little more than an assertion that nations comply with the law. After all, why should we think that the presiding norm is one of compliance rather than one of ignoring legal commitments, or perhaps a norm of pursuing the narrow self-interest of the nation or its leaders? Furthermore, observing that a norm generates compliance does not offer an explanation for compliance since we have no theory of why norms operate as a force for compliance. Without a theoretical framework, the norms argument is not helpful in nnderstanding state behavior.

Consider, for example, the managerial model's claim that while dispute resolution is a useful tool that may enhance compliance, it need not be mandatory and, furthermore, a failure to comply need not result in binding sanctions. Underlying this view of dispute resolution is the belief that a failure to comply is the result of a mistake or a lack of communication. Dispute resolution, then, need only serve as a forum where states share information and clarify their expectations. In fact, more can be said under the managerial model. Because states are, by assumption, cooperative, there is no need for binding law of any kind. Simple statements of interest and intent, without any notion of commitment, are sufficient to resolve most coordination games. Therefore international law as conceived by this model need not be binding or irrevocable. It is precisely because states do not have to be compelled to act in a particular way that dispute resolution does not have to be compulsory or backed by sanctions.

When a state violates the law because the law is contrary to its interests, however, the managerial model breaks down. When the states' interests are at odds, as is true in instances of intentional violation, the states conduct negotiations "in the shadow" of potential sanctions. In the absence of such sanctions the offending party has no incentive to accept a negotiated solution that involves any punishment or constraint on future behavior. This, in turn, implies that the law provides no incentive to comply. If one makes dispute resolution mandatory, on the other hand, and provides some form of sanction for a failure to comply with the ruling, it is possible to increase compliance even outside of coordination games.

The managerial model, then, is a useful but incomplete model of compliance. ${ }^{30}$ As long as one is only interested in coordination games, it

29. See infra note 31 and accompanying text.

30. Oona Hathaway suggests that the Chayes \& Chayes approach might actually be a more general theory that operates in a manner not unlike the theory presented here. See Oona A. Hathaway, 
provides a good guide to compliance and national behavior. If one seeks to understand situations where states make agreements that call upon them to act against their own interests in exchange for concessions from other states, a different model is needed. Part II of this Article advances such a model.

\section{Consent and Treaties}

An alternative theory of the relevance of international law, and probably the most commonly held rationale for the relevance of international law to national conduct, especially in the context of treaties, is based on the notion of consent. ${ }^{31}$ The consent-based theory begins with the claim that states are not subject to any obligation to which they did not consent. ${ }^{32}$ The second, and more problematic, step in the consent-based theory invokes the oft-repeated statement that states should obey treaties. ${ }^{33}$ Based on this reasoning, proponents of consent-based theories argue that a state's consent generates a legal obligation which leads to compliance. ${ }^{34}$

Do Human Rights Treaties Make a Difference?, I II Y YLE L.J. 1935, 1950 n.46 (2002) ("Guzman's work could be seen as providing a formal model of the amorphous threat of alienation from the 'complex web of international arrangements' that is emphasized by Chayes and Chayes."). If Chayes' model were indeed a less formal version of the model presented here, however, one could not conclude, as they do, that a managerial approach is preferred. The model here relies on sanctions (both direct and reputational) to encourage compliance and the managerial approach is not, in general, the best way to make such sanctions work. The core of the managerial model is clarity and commumication ex ante to prevent conflict. In contrast, the reputational model considers how sanctions, applied ex post, affect the compliance decisions of self-interested states.

31. See Setear, supra note 3 , at 156 ; Smith, supra note 5 , at $1565-66$. Though most frequently discussed in the context of treaties, the use of consent as an explanation for the binding character of international law is also present in discussions of CIL. See BYERS, supra note 7, at 7; M. O. Chibundu, Making Customary International Law Through Municipal Adjudication: A Structural Inquiry, 39 VA. J. INT'L L. 1069, 1122 (1999).

32. "The rules binding upon states therefore emanate from their own free will .... Restrictions upon the independence of states cannot therefore be presumed." S.S. Lotus Case, 1927 P.C.I.J. (ser. A) No. 10, at 18; see also Louis Henkin, International Law: Politics, Values and Functions, 216 RecueIL Des Cours D'ACADEMIE DE DroIt INT'L 9, 27 (1989) ("[A] state is not subject to any external authority unless it has voluntarily consented to such authority.").

33. See Vienna Convention on the Law of Treaties, May 23, 1969, art. 26, 1155 U.N.T.S. 331 ("Every treaty in force is binding upon the parties to it and must be performed by them in good faith."); Chayes \& Chayes, supra note 1, at 185 ("It is often said that the fundamental norm of international law is pacta sunt servanda (treaties are to be obeyed).") (footnote omitted).

34. Because consent-based theories fail to explain why the theory prevents nations from simply withdrawing their consent, critics argue that these theories cannot ultimately explain why international law is binding. See L. Brierly, The Law of Nations: An Introduction to the INTERNational LAIV of PEACE 51-54 (Sir Humphrey Waldock ed., 6th ed. 1963); Smith, supra note 5; Setear, supra note 3 , at 160 . Absent the ability to make irrevocable commitments, the argument goes, a nation could simply withdraw its consent from any treaty found to be inconvenient. This criticism, popular though it is, is unsatisfactory. If one can assert that consent is enough to bind states, why can it not be similarly asserted that it is possible to consent to irrevocable commitments? Accord Setear, supra note 3, at 161 ("I see nothing casuistic in the argument that parties to a treaty consent not only to particular terms but also to the general notion that their consent must not be withdrawn."). 
The consent-based arguments are logically flawed because they confuse a (possibly) necessary condition for states to be bound with a sufficient condition. In other words, the consent-based theory only observes that states are not bound to international agreements unless they consent to them. This initial presumption, even if assumed to be correct, ${ }^{35}$ does not lead to the conclusion that consent is enough to bind a state. Consent, by itself, does not provide states with an incentive to obey the law. The standard rendition of consent-based theories fails to address this point. Rather, advocates of the theory simply recite the maxim that "treaties are to be obeyed." ${ }^{36}$ This statement, however, either is devoid of content or assumes the conclusion. If the statement is read to mean that treaties should be obeyed, as a normative matter, it says nothing about how states will actually behave. If, on the other hand, it is read to mean that states do, in fact, obey treaties, then it is simply assuming compliance without explaining it.

\section{Legitimacy Theory}

Thomas Franck has advanced a general theory of international law that has come to be known as legitimacy theory. ${ }^{37}$ The fundamental premise underlying legitimacy theory is that states obey rules perceived to have "come into being in accordance with the right process." ${ }^{38}$ Franck argues that four factors determine whether a state complies with international obligations: determinacy, ${ }^{39}$ symbolic validation, ${ }^{40}$ coherence, ${ }^{41}$ and adherence. ${ }^{42}$ Where these four factors are present, legitimacy theory predicts a strong pressure toward compliance, and where they are absent, it predicts a very limited impetus in that direction. ${ }^{43}$ In the end, however, Franck's legitimacy theory takes the inquiry no further than does consent theory.

Legitimacy theory leaves too many of the central questions regarding compliance and national behavior in the black box of "legitimacy" without explaining why states do or should care about legitimacy. For instance, the claim that nations violate international rules because of the "perceived lack

35. I will argue below that it is not quite accurate. See infra Part III.A.5. (discussing how states can be "bound" by informal agreements, custom, and practice).

36. See Chaycs \& Chayes, supra note 1, at $\mathbf{I} 85$.

37. ThOMas M. Franck, FaIRness in InTernational Law and Instrmutions (1995) [hereinafter FRANCK, FAIRNEss]; Franck, supra note I6.

38. Franck, supra note 16 , at 706 .

39. Under Franck's theory, determinacy refers to the clarity of the rule or norm. See id. at 713-25.

40. Symbolic validation refers to the presence of procedural practices or rituals that provide a rule with symbolic importance and legitimacy. See id. at 725-35.

41. Coherence refers to the connection between rational principles and the rule. See id. at 735-51.

42. Adhcrence refers to the connection between the rule and those secondary rules used to interpret and apply the primary rule. See id. at 75I-59.

43. In more general terms, Franck describes legitimacy as "a property of a rule ... which itself exerts a pull toward compliance... because those addressed believe that the rule or institution has come into being and operates in accordance with generally accepted principles of right process." FRANCK, FAIRNESS, supra note 37, at 24. 
of legitimacy of the actual or proposed rules themselves and of the rulemaking and rule-applying institutions of the international system"44 simply begs the question. Why should we expect nations to honor rules that enjoy legitimacy while ignoring others? In any event, the claim that legitimacy is the driving force behind compliance is an assertion, rather than the result of a theoretical framework or empirical study. ${ }^{45}$

Accordingly, legitimacy theory fails for the same reason that the consent-based theory fails: neither provides a model of compliance so much as an assertion that nations obey the law. Franck's theory fails to explain why "legitimacy" leads to compliance, why the four factors are important, how they interact with other measures of a nation's self-interest, and why states violate laws with which they had previously complied. ${ }^{46}$

\section{Transnational Legal Process}

Professor Harold Koh has advanced another theory of international law, termed transnational legal process. The theory focuses on how public and private actors interact in various fora, on both domestic and international levels, to make, interpret, enforce, and mternalize rules of transnational law. ${ }^{47}$ Transnational legal process looks to a wide set of decisionmakers to explain conduct, including multinational corporations, nongovernmental organizations, international organizations, private individuals, and others. Koh argues that as transnational entities-including both state and nonstate actors-interact, patterns of behavior and norms emerge and are internalized, leading to their incorporation within the domestic legal institutions of states and, in turn, compliance. ${ }^{48}$

The claim that domestic legal institutions play a critical role im international law is certainly correct. The claim that domestic institutions somehow internalize transnational legal norms and thereby cause compliance is probleniatic. Transnational legal process theory provides no explanation for why or how certain legal norms are imternalized. Even if one assumes, as does Professor $\mathrm{Koh}$, that international legal norms are

44. Franck, supra note 16 , at 710 .

45. "To the extent rules exhibit [legitimacy,] they appear to exert a strong pull on states to comply with their commands. To the extent [legitimacy is] not present, rules secm to be easier to avoid by a state tempted to pursue its short-term self-interest." Id. at 712. Notice here that Franck implies the existence of a tension between a state's self-interest and its willingness to comply. In the model presented in this Article, states always act in their own self-interest.

46. Additional criticisms of legitimacy theory have becn advanced elsewhere. Among the complaints are claims that the four factors involved are vague and difficult to evaluate, and that the theory does not tell us how to aggregate thein. See Koh, supra note 3, at 2641-45.

47. See Harold H. Koh, Transnational Legal Process, 75 NeB. L. REv. I81, 183-84 (1996) [hereinafter Koh, Legal Process]; Koh, supra note 3.

48. See Koh, Legal Process, supra note 47, at 204 ("It is through this repeated process of interaction and internalization that international law acquires its 'stickiness,' that nation-states acquire their identity, and that nations define promoting the rule of imternational law as part of their national self-interest."). 
internalized, one would expect domestic legal norms-in particular, the norm of pursuing the interests of domestic decision-makers-to be internalized more readily. When international legal norms are at odds with the self-interest of the state, it is difficult for transnational legal process theory to explain why international norms would triumph. Moreover, if domestic concerns triumph, then the internalization of international legal norms has no apparent impact on outcomes.

In addition, Koh appears to assume that repeated interaction leads to the internalization of norms that are consistent with international law, but this assumption is not explained. It seems equally plausible that the internalized norms are unrelated to international law. For example, rather than internalizing norms of international law, transnational actors might internalize the norm that powerful nations triumph over weaker nations, or that economic influence resolves international disputes.

Without an understanding of why domestic actors internalize norms of compliance in the international arena, and a theory of why this internalization tends toward compliance, the theory lacks force. Like the consentbased and legitimacy theories, the transnational legal process theory is ultimately founded on the unsupported assumption that states obey the law. It differs from prior theories in that it considers the relevant unit of analysis to be individuals and interest groups rather than the state, but it still fails to ask why these actors follow international law. Without a more complete theory of why these actors follow the law, the theory remains unsatisfactory.

\section{B. International Relations Theories}

Although traditional approaches to legal scholarship remain common, a new approach challenging the traditional methodology has emerged. This approach comes primarily from political science and the theory of international relations, though it also has roots in the economics literature. While a detailed taxonomy and review of the international relations literature is beyond this Article's scope, this Section offers a thumbnail sketch of the three most relevant schools of thought: neorealist theory, institutionalist theory, and liberal theory. ${ }^{49}$

\section{Neorealists}

Neorealist theory, an outgrowth of classical realism, ${ }^{50}$ treats states as unitary actors and as the relevant unit in international relations. According

49. Professor Abbott has usefully categorized the intemational relations literature. See Abbott, Prospectus, supra note 5.

50. For a discussion of classical realism, see Edward H. CarR, The Twenty Years' CRISIS I919-I939 (1962); George F. Kennan, American Diplomacy igoo-I950 (1951); Hans J. 
to neorealist theory, international cooperation will exist with respect to a particular issue only when it is in the interest of the affected states. ${ }^{51} \mathrm{Neo}-$ realists posit that states primarily seek power and security, and international relations are largely driven by power. ${ }^{52}$

Some scholars conclude that international law has little or no independent impact on the behavior of states. ${ }^{53}$ By this view, compliance with international law is explained as a coincidence between international lawwhose content, in any event, is said to be largely controlled by powerful states-and the self-interest of nations. ${ }^{54}$ International law, therefore, is simply an epiphenomenon.

Criticisms of neorealism can be found in the international relations literature. ${ }^{55}$ For present purposes, it is sufficient to simply identify some of the difficulties with adopting a realist perspective on international law. Foremost among the problems for the neorealist conclusion that international law is irrelevant is the difficulty of reconciling it with the observation that a great deal of time, energy, and money are spent in the creation of international law. For example, the Uruguay Round negotiations, leading to the establishment of the World Trade Organization ("WTO"), lasted eight years, consumed enormous resources, and affected the political fortunes of governments around the world.

If neorealists are correct that international law does not matter, why did states devote so many resources to these negotiations? Just as rational individuals would not expend resources to complete a contract that has no effect on behavior, there is no reason to think that states would spend resources to complete treaties and other agreements that have no impact on states' behavior. Nor would states (or nonstate actors) expend resources to influence the status of $\mathrm{CIL}$, as has been done in such fields as foreign

Morgenthau, Politics Among Nations: The Struggle for Power and Peace (1948); Hans J. Morgenthau, Positivism, Functionalism, and International Lav, 34 Am. J. Int'l L. 260 (1940).

51. See Joseph M. Grieco, Anarchy and the Limits of Cooperation: A Realist Critique of the Newest Liberal Institutionalism, 42 INT'L ORG. 485 (1988).

52. See id.

53. See Robert H. Bork, The Limits of "International Law", 18 NAT'L INT. 3 (1989-90); Francis A. Boyle, The Irrelevance of International Lav: The Schism Between International Law and International Politics, 10 CAL. W. INT'L L.J. 193 (1980).

54. See Stephen D. Krasner, Sovereignty: Organized Hypocrisy (1999); Abbott, Atrocities, supra note 5, at 364-65; Slaughter Burley, supra note 5, at 217 ("For Waltz, norms of any sort, qua norms, lacked independent causal force."). Hans Morgenthau, one of the great realists, conceded that international law is generally observed, but considered this to be the result of either power relations or convergent interests. See Beth A. Simmons, Compliance with International Agteements, 1 ANN. Rev. Pol. ScI. 75, 79 (1998); see also Morgenthau, supra note 50; Morgenthau, supra note 50.

55. For a detailed discussion of the problems with neorealism, see NeOREALISM AND ITs CRITICS (Robert O. Keohane ed., 1986). 
investment, ${ }^{56}$ human rights, ${ }^{57}$ and environmental law, ${ }^{58}$ if such efforts would have no impact.

Other observations also undermine the conclusion that international law is irrelevant. For instance, when states claim that an international law has been violated (though it is not clear why anyone would even bother to make such a claim), their accused states would have no reason to proclaim its innocence or expend resources fighting to exonerate themselves, as they so often do. ${ }^{59}$ Furthermore, the existence of international dispute-resolution procedures cannot be explained if international law does not matter. A fmal problem for the neorealist camp is that empirical and anecdotal evidence has begun to emerge indicating that international law does, indeed, influence state behavior. ${ }^{60}$

\section{Liberal Theory}

A second international relations theory, known as liberal theory, ${ }^{61}$ focuses on interest-group dynamics within each state. ${ }^{62}$ Liberal theory begims with the assumption that the key actors in international relations are individuals and private groups, rather than states. Accordingly, the theory is interested in the particulars of domestic politics $m$ addition to the

56. See Andrew T. Guzman, Why LDCs Sign Treaties that Hurt Them: Explaining the Popularity of Bilateral Investment Treaties, 38 VA. J. INT'L L. 639, 644-51 (1998).

57. Frank Newman \& David Weissbrodt, International Human Rights: Law, Policy, AND PROCESS 18 (2d ed. I996).

58. See The Implementation and EfFectiveness of International Environmental Commitments: Theory and Practice (David G. Victor et al. eds., 1998).

59. See HenKIN, supra note 1, at 43 ("While nations, generally, still deny that they are violating international law, often the denial merely falsifies the facts.").

60. See, e.g., Ronald B. Mitchell, Compliance with International Treaties: Lessons from Intentional Oil Pollution, 37 Env't 10 (1995); Stephen M. Schwebel, Commentary, in Compliance WITH Judgments of INTERnational Courts 39, 39 (M.K. Bulterman \& M. Kuijer eds., 1996) (arguing that states tend to comply with the decisions of international tribunals); Simmons, supra note 2 , at 325 (presenting an empirical study of state compliance with International Monetary Fund obligations and concluding that "international law has a significant impact on governments' behavior.").

61. See Andrew Moravcsik, Taking Preferences Seriously: A Liberal Theory of International Politics, 51 INT'L ORG. 513 (1997); Anne-Marie Slaughter, International Law in a World of Liberal States, 6 EuR. J. INT'L L. 503 (1995) [hereinafter Slaughter, Liberal States]; Anne-Marie Slaughter, The Liberal Agenda for Peacc: International Relations Theory and the Future of the United Nations, 4 TranSNat'L L. \& Contemp. Probs. 377 (1995) [hereinafter Slaughter, Liberal Agenda]. For a version of liberal theory in the legal literature, see Koh, Legal Process, supra note 47, at 183-84 (I994); Koh, supra note 3.

62. The most prominent advocate of the liberal theory within the legal academy is Professor Anne-Marie Slaughter, who argues that compliance with international law is determined in siguificant part by the domestic structure of a country. She claims that states with a "liberal" structure, meaning representative government, protection of civil and political rights, and a judicial system guided by the rule of law, tend to follow international law, at least among themselves. See Anne-Marie Burley, Law Among Liberal States: Liberal Internationalism and the Act of State Doctrine, 92 Colum. L. Rev. 1907, 1920-21 (1992); Slaughter Burley, supra note 5; Slaughter, Liberal States, supra note 61. 
interaction of states. A focus on subnational entities leads to the study of institutions such as courts, legislatures, and administrative agencies. ${ }^{63}$

Liberal theory of international law is hampered by the complexity of a model that rejects the assumption of unitary state actors. ${ }^{64}$ An examination of compliance within a liberal framework is really an examination of the domestic politics of countries that might lead to a decision to comply with international law. The problem is that interactions among domestic interest groups are unpredictable, and the results may not be stable over time. Because of the complexity of interest-group politics, it is difficult to generate predictions about how nations behave. ${ }^{65}$ The problem with liberal theory, then, is that it is overly complex. Because it is better suited to positive accounts of behavior rather than to predictions, it does not lead to a general model of compliance. ${ }^{66}$

\section{Institutionalist Theory}

The third important category of international relations theories is institutionalism. ${ }^{67}$ Like neorealism, institutionalism views states as the primary international actors and treats them as rational unitary agents interacting in an anarchical world. ${ }^{68}$

63. See Laurence R. Helfer \& Anne-Marie Slaughter, Toward a Theory of Effective Supranational Adjudication, 107 YALE L.J. 273 (1997).

64. Liberal theories are closely related to public choice theories, found in both domestic and international law. 1 have previously discussed the difficulty of using public-choice models in a discussion of state behavior that goes beyond a case study. See Andrew T. Guzman, Choice of Law: New Foundations, 90 GEo. L.J. 883, 900-04 (2002).

65. See Robert O. Keohane, AFTER Hegemony: CoOperation and Discord in the World Political ECONOMY 25 (1984) ('Parsimonious theory, even as a partial 'first cut,' becomes impossible if one starts analysis [at the subnational level], amidst a confusing plethora of seemingly relevant facts."). It should, however, be noted that liberal theorists are attempting to generate general theoretical claims despite the challenge of doing so within a liberal model. See Helfer \& Slaughter, supra note 63.

66. The complexity of liberal theories, of course, is an asset in certain circumstances, such as in attempts to explain the results of case studies.

67. See Abbott, Atrocities, supra note 5, at 365. Among the important and useful institutionalist contributions are Duncan Snidal, The Game Theory of International Politics, 38 WorLd PoL. 25 (1985) [hereinafter Snidal, Game Theory]; Duncan Snidal, The Limits of Hegemonic Stability Theory, 39 INT'L ORG. 579 (1985); Duncan Snidal, Coordination Versus Prisoners' Dilemma: Implications for International Cooperation and Regimes, 79 AM. PoL. ScI. Rev. 923 (1985) [hereinafter Snidal, Prisoners' Dilemma]; Arthur A. Stein, Coordination and Collaboration: Regimes in an Anarchic World, 36 INT'L ORG. 299 (1982); Robert Jervis, Cooperation Under the Security Dilemma, 30 WorLD PoL. 167 (1978); Robert Jervis, Security Regimes, 36 INT'L ORG. 357 (1982); Kenneth A. Oye, Explaining Cooperation Under Anarchy: Hypotheses and Strategies, 38 WORLD POL. 1 (1985); CoOperation Under ANarchy (Kenneth A. Oye ed., 1986); Stephan Haggard \& Beth A. Simmons, Theories of International Regimes, 41 INT'L ORG. 491 (1987).

68. See Robert Axelrod, The Evolution of Cooperation 3 (1984); Robert Axelrod \& Robert O. Keohane, Achieving Cooperation Under Anarchy: Strategies and Institutions, 38 WORLD PoL. 226, 226 (1985). Many, and perhaps most, institutionalists recognize that state decisions are the product of a domestic political process in which different interests compete for influence. Nevertheless, as I do in this Article, institutionalists usually model the state as a single actor to simplify the analysis. See Abbott, Atrocities, supra note 5, at 365. 
Unlike neorealists, however, institutionalists believe that international cooperation is possible, and that international institutions can play a role in facilitating that cooperation. Specifically, institutionalists argue that institutions can reduce verification costs in international affairs, reduce the cost of punishing cheaters, and increase the repeated nature of interaction, all of which make cooperation more likely. ${ }^{69}$

\section{Theoretical Approach of This Article}

This Article draws upon the institutionalist tradition of international relations to develop a model of compliance with international law. ${ }^{70}$ Using a repeated-game model of national behavior, it demonstrates that international law can affect the behavior of states. Consistent with both neorealism and institutionalism, it assumes that states are independent and that they act only in their own self-interest. Unlike most institutionalist discussions of international law, however, treaties do not represent the exclusive focus of the Article. ${ }^{71}$

While this Article does not adopt a liberal approach, it is not in conflict with that school. Rather, this theory of compliance complements liberal theory. This Article assumes, without specifying the particular goals of each state, that states are unitary actors engaged in the pursuit of national goals. Liberal theory is one way of studying these goals. Thus, one can view liberal theory as a methodology whose output-the policy desires of states-is an input for the theory of compliance presented here.

II

\section{A THEORY OF COMPLIANCE}

At a minimum, a sound theory of compliance must explain both (1) instances of compliance with international law and (2) instances of violation. As discussed in the previous Part, traditional legal theories of compliance have been unable to provide a constructive theoretical framework for compliance, in part because they cannot explain instances of violation. Neorealists, on the other hand, argue that international law has no effect on national behavior; explaining breach but not compliance. ${ }^{72}$

This Part presents a theoretical model of compliance that explains both how international law can affect state behavior and why states

69. See KeOHANE, supra note 65 , at 246.

70. The most important prior work with a similar approach is that of Robert Keohane, especially KEOHANE, supra note 65.

71. See Abbott, Atrocities, supra note 5, at 366 ("In practice, though, institutionalist scholarship focuses on treaties.").

72. Neorealists argue that instances of "compliance" are merely cases in which the nation's policy happens to coincide with international law. This claim cannot explain other elements of international law, however, including the existence of treaties, disputes over compliance, and so on. See supra Part I.B.1. 
sometimes violate that law. First, it develops a one-period model to demonstrate how the irrelevance of international law is modeled. Second, the assumption of a single period is relaxed, showing how in a model with repeated state interactions, one can develop a theory in which international law matters.

With respect to government behavior, the model makes standard assumptions about states: they are rational, they act in their own selfinterest, and they are aware of the impact of international law on behavior. ${ }^{73}$ Although it is assumed that states act in a self-interested fashion, no assumption is made regarding the way in which states identify their selfinterest. The traditional way of modeling state interest assumes that the government pursues the public interest. Public-choice theory, an alternative approach, views government decisions as the product of interest-group politics and argues that these decisions will not, in general, lead to behavior that is consistent with the national interest. Under this public-choice view, decision-makers are modeled as individuals pursuing their own objectives rather than as faithful agents of their constituencies. ${ }^{74}$ The advantage of a public-choice approach is its ability to provide a positive account of government activity that is difficult to explain through more traditional models of government behavior. The difficulty in applying public choice to normative analysis, however, is that the outcome of interest-group politics is very difficult to predict. ${ }^{75}$ For the purposes of this Article, it is not necessary to choose between the public-interest and public-choice models because the Article does not attempt to model the process by which states determine their national goals. Rather, this theory takes national goals as given, and the model explains the conditions under which the pursuit of such goals leads to compliance with international law. For this reason, the Article can accommodate both theories of government behavior. ${ }^{76}$

\section{A. A Theory of the Irrelevance of International Law}

The first step in understanding this Article's theory of compliance is to understand the theory of the irrelevance of international law. As shown below, the simplest rational-actor model of country behavior leads to the conclusion that international law does not matter. Once that basic model is

73. See Keohane, supra note 65, at 27; Abbott, Prospectus, supra note 5, at 349.

74. See Daniel A. Farber \& Philip F. Frickey, Law \& Public Choice: A Critical INTROduction 17 (1991); Michael E. Levine \& Jennifer L. Forrence, Regulatory Capture, Public Interest, and the Public Agenda: Toward a Synthesis, 6 J.L. EcoN. \& ORG. 167, 169 (1990) ("[Public choice] analysts postulate that people should be expected to act no less rationally or self-interestedly as politicians or bureaucrats than they do in the course of their private exchanges in markets."); George J. Stigler, The Theory of Economic Regulation, 2 BELL J. Econ. \& MGMT. ScI. 3 (1971).

75. See Abbott, Prospectus, supra note 5.

76. For a more complete discussion of public choice issues and international law, see Guzman, supra note 64 , at 900-04. 
understood, it is possible to identify the assumptions that generate the irrelevance result and then relax those assumptions to develop a model of compliance in which international law matters.

The most basic model of country behavior is a one-shot game in which states decide whether or not to comply with a particular rule of imternational law. ${ }^{77}$ For concreteness, suppose that two countries have agreed to a ban on satellite-based weapons and the decision at hand is whether or not to comply with that agreement. Assume that (1) each country is better off if it violates the agreement while the other country complies, and (2) both are better off if they both comply than if they both violate. This game, a simple prisoner's dilemma, is presented in Figure A, and the well-known equilibrium is for both countries to violate their international obligation.

FIGURE $A^{78}$

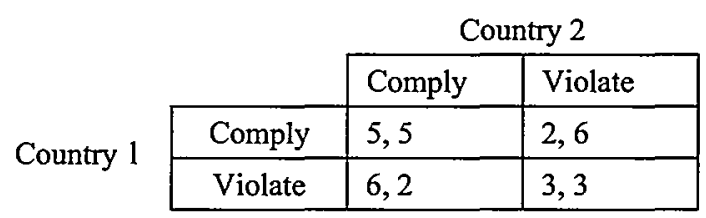

If this game is a fair representation of international relations, we would expect to see a world of chaos in which cooperation and compliance with international law are nonexistent. Such an observation is clearly at odds with what we observe. ${ }^{79}$

Though international law scholars have cited the widespread compliance with international commitments as evidence that international law matters, ${ }^{80}$ a simple extension of the above model shows that a high level of compliance need not imply that international law affects national behavior. Adding an additional round to the game explains how countries can regularly act in a manner consistent with their international obligations even if those obligations have no impact on state behavior. In an extension of the above model, the game is unchanged, but represents only a portion of a larger game. In the larger game, there is an initial period in which the state

77. The basics of game theory are available in many other sources, and they will not be repeated here. For relevant discussions in the context of international law, see Setear, supra note 3; Abbott, Prospectus, supra note 5; Goldsmith \& Posner, supra note 5. For more comprehensive presentations of game theory, see Douglas G. Baird et al., Game Theory and the LaW (1994); ERIC Rasmusen, Games and Information: An Introduction to Game Theory (1989); Drew Fudenberg \& Jean TiRole, Game TheORY (1991).

78. The first entry in each cell represents the payoff to Country 1 while the second entry represents the payoff to Country 2.

79. In the famous words of Henkin, "almost all nations observe almost all principles of international law and almost all of their obligations almost all of the time." See HENKIN, supra note 59, at 47 .

80. Id. 
of nature is determined. Assume that there are two possible states of nature labeled "good" and "bad." "Figure A, and the related discussion, represent the bad state of nature. In the satellite-based weapons treaty example given above, the bad state of nature corresponds to a situation in which the parties have an incentive to develop space-based weapons in spite of their treaty obligations.

The good state of nature, represented by Figure B below, corresponds to the situation in which the parties have an incentive to comply with treaty provisions independent of their international obligations. Suppose that the technology for the construction of a satellite-based weapons system is too primitive to make the system effective and that the cost is prohibitive, making it a poor use of government resources. In this situation, neither party would develop satellite-based weapons, even in the absence of an international agreement.

FIGURE B

\begin{tabular}{|c|c|c|c|}
\hline & \multicolumn{2}{|c|}{ Country 2} \\
\hline & & Comply & Violate \\
\hline \multirow{2}{*}{ Country 1} & Comply & 10,10 & 6,8 \\
\hline & Violate & 8,6 & 4,4 \\
\hline
\end{tabular}

In Figure B, if both countries violate the treaty, they are both worse off because they would have expended resources on an unreliable system. If Country 1 violates the treaty, that country is worse off as a result of the expended resources, and Country 2 also suffers a loss because even an unreliable weapons system in the hands of a potential enemy is undesirable. If both comply with the treaty, however, both enjoy the maximum possible payoff. More importantly, compliance is the dominant strategy for both parties. In other words, each country is better off if it complies with the treaty, regardless of the action taken by the other party.

Combining the good and bad outcomes yields a theory of national behavior consistent with the observation that countries obey their international obligations much of the time. Further, the analysis is also consistent with the view that international law does not matter. At times, a state's behavior happens to coincide with its international obligations, as in the example of states choosing not to develop satellite-based weapons because the technology is inadequate. At other times, states violate their obligations, as in the example of states choosing to develop such weapons despite the presence of a treaty. In neither case does the existence of an international agreement affect behavior.

81. Limiting the number of states to two makes the exposition simpler but does not affect the results. 
This model in which international law is irrelevant has been advanced by the neorealist school in international relations. ${ }^{82}$ Though it is simple and elegant, and may explain instances of both observed compliance with international obligations and violations thereof, this theory cannot explain other observed behavior. It cannot explain, for example, why countries enter into treaties in the first place. The negotiation of international treaties and other agreements consumes resources that a state could use in other ways. If international law does not have any impact on behavior, there is no reason for a country to waste resources on international legal conventions and negotiations. Similarly, this simple model is unable to explain why countries invest resources to demonstrate that they are in compliance with international law; if the model is correct that international law has no impact on behavior, countries should ignore it. What we observe, however, are attempts by countries to justify their actions under international law. The model also fails to explain the existence of international law disputeresolution processes to which nations sometimes submit their disputes. If international law does not matter, there is no reason for such procedures. Finally, the theory is contradicted by empirical data suggesting that international law does, indeed, influence state behavior. ${ }^{83}$

In a finitely repeated prisoner's dilemma like the one presented above, the irrelevance of international Iaw is inevitable. By adopting a flnitely repeated game, one ensures that the equilibrium in a prisoner's dilemma context is noncooperative behavior ("defection"). This amounts to an assumption that cooperation will fail and that international law does not matter.

\section{B. A Theory of the Relevance of International Law}

In a domestic setting, even one-shot prisoner's dilemmas can yield the cooperative outcome through the use of contract. Suppose, for example, that two individuals agree to swap vacation homes for the summer. They each agree to care for the other's home, including the performance of certain regular maintenance chores. While on vacation, however, maintenance is time consuming, expensive, and boring, so there is an incentive to avoid it. The standard prisoner's dilemma model predicts that neither party will honor their promise to care for the other's home. Despite this tendency towards shirking, if their agreement is legally enforceable, a shirking party must pay damages which, if high enough, will induce the parties to carry out the promised maintenance. Law changes the payoffs and solves the prisoner's dilemma by imposing a penalty against the shirking party. To change the equilibrium, the penalty must change the payoffs enough to make cooperation a dominant strategy for each party.

82. See supra note 53.

83. See supra note 60. 
Just as compliance with promises at the domestic level requires the existence of damages, a model of compliance with international law requires a mechanism through which nations that violate an agreement are sanctioned. The finitely repeated game of the previous Section can generate a model of effective international law only if there exists an entity that can sanction those who violate international law, much like courts sanction domestic violations. Those who argue that international law has little or no inpact on national behavior, therefore, are implicitly claiming that the existing penalties for violations of international law are insufficient to change the equilibrium of the game. As mentioned, the use of a finitely repeated game without a coercive compliance mechanism is equivalent to assuming that result.

To generate a model in which international law matters, then, it is necessary to identify a mechanism through which violations are sanctioned. Even those who believe that international law plays an important role in regulating conduct in the international community must concede that there is, at best, a weak system of meting out punishments for violations of law. ${ }^{84}$ Nevertheless, a sound model of international law must turn on the impact of sanctions. It is important to note, however, that the term "sanction" must encompass more than just direct punishments resulting from a failure to live up to one's international obligations. Sanctions include all costs associated with such a failure, including punishment or retaliation by other states, and reputational costs that affect a state's ability to make commitments in the future. ${ }^{85}$

To take the role of reputation into account, it is useful to remember one of the most basic elements of contract theory: in the absence of transaction costs, parties to a contract will negotiate to the most efficient outcome. ${ }^{86}$ This implies that the best possible rule, both for individuals in the domestic context and for states in the international context, is one in which the parties have complete freedom of contract, including the ability to make irrevocable commitments. In the domestic setting, the power to commit oneself exists because the courts stand ready to enforce contracts. ln the international setting, states must rely on the imperfect system of

84. That said, it would be a mistake to completely disregard the existing set of sanctions altogether. See Lori Fisler Damrosch, Enforcing International Law Through Non-Forcible Measures, 269 RECUEIL DES COURS 9, 19-22 (1997) (outlining the enforcement mechanisms that currently exist).

85. I should note that internationaI legal scholars have long understood that reputation matters. Although the effect of reputational constraints have not previously been explored as formally and fully as they are in this Article, one can find comments scattered throughout the international law literature implying that scholars understood all along that reputation and repeat play were important in the intemational legal system. See, e.g., Ian Johnstone, Treaty Interpretation: The Authority of Interpretive Communities, 12 MICH. J. INT'L L. 371, 391 (I99I) ("Because all States have a stake in maintaining a reputation for good faith compliance with treaty commitments, they will hesitate before publicly announcing a construction likely to be branded as improper or far-fetched.").

86. See A. Mitchell Polinsky, An Introduction to Law ANd Economics 31 (2d ed. 1989). 
international sanctions and reputational effects. Although states are not able to make fully irrevocable commitments, the greater a state's ability to commit itself, the better off it is. ${ }^{87}$

The model of international law presented in this Article is an infinitely repeated game that operates as follows. ${ }^{88}$ Any given international obligation is modeled as a two-stage game. In the first stage, states negotiate over the content of the law and the level of commitment. ${ }^{89}$ In the second stage, states decide whether or not to comply with their international obligations. International law affects a state's self-interest, and thus its compliance decision, in two ways. First, it can lead to the imposition of direct sanctions such as trade, military, or diplomatic sanctions..$^{90}$ Second, it can lead to a loss of reputational capital in the international arena..$^{91}$ If the direct and reputational costs of violating international law are outweighed by the benefits thereof, a state will violate that law..$^{92}$

87. There are some circumstances in which the ability to commit may be harmful. For example, a country that is being asked by an ally to promise military aid in the event of war may be better off if it simply is unable to make such a commitment because it can then avoid the risk of involvement in a war without angering the requesting country. An inability to commit, however, is only beneficial in exceptional cases. As a general matter, states, like private parties, are better off if they are able to make irrevocable commitments.

88. International relations theorists are aware of how an infinitely repeated game can affect the analysis and have used such models to advance theories of international cooperation. The model presented here resembles some of these theories. See KeoHaNe, supra note 65, at 75; MichaEL TAylor, The Possibility of CoOperation (Jon Elster \& Gudmund Hernes eds., 1987); Anne E. Sartori, The Might of the Pen: A Reputational Theory of Communication in International Disputes, 56 INT'L ORG. 121 (2002). Others have used infinitely repeated games to model international law, though not in the way it is used here. See Setear, supra note 3; Snidal, Prisoners' Dilemma, supra note 67; Snidal, Game Theory, supra note 67.

89. The term "negotiate" is used as shorthand. This stage represents the decision of one or more countries to enter into an international agreement, regardless of whether the terms of that agreement are bargained over at the time. For example, in the case of CIL, there is no process of formal negotiations. Nevertheless, a country can seek to reduce its obligation by remaining a persistent objector. Another example would be the decision by a state to join (or not join) an existing agreement. For example, if Poland were invited to join the European Union, its decision to accept or decline the invitation would qualify as "negotiation" for present purposes.

90. It can also lead to a sanction through formal dispute-settlement mechanisms, such as those of the WTO. Under appropriate circumstances, these sanctions are especially likely to be successful, as is discussed infra Part III.C.

9I. I am not the first to identify reputation as an important issue in international law. See HENKIN, supra note 59, at 46-59 (listing factors in a country's decision to observe international law, including reputational consequences); Robert $\mathrm{O}$. Keohane, International Relations and International Law: Two Optics, 38 HARv. INT'L L.J. 487, 496-99 (I997).

92. A short example may help to clarify the intuition involved. The United States has entered into the North American Free Trade Agreement ("NAFTA"), a trade agreement with Canada and Mexico. The North American Free Trade Agreement, Dec. 17, 1992, Can.-Mex.-U.S., 32 I.L.M. 289, 32 I.L.M. 605 (entered into force Jan. 1, 1994), availablc at http://www.nafta-sec-alena.org/english/index.htm [hereinafter NAFTA]. Suppose that political pressure develops in the United States, calling for a tariff on the import of certain kinds of clothing, and that the primary impact of this action would be to harm Mexican producers. Assume that the tariff being considered would represent a violation of NAFTA. In the absence of a trade agreement, the United States would be free, under international law, to impose a tariff. (Though the United States would also have to worry about its WTO obligations. For simplicity, 
In the first period, states decide whether or not to enter into a legal obligation. For present purposes, an obligation is defined as a promise to other states; it could be a treaty, an informal agreement, or any other form of promise. If no promise is made, the state is free to engage in whatever conduct it chooses in the second period without suffering any sanction. ${ }^{93}$

The second period reveals the state of the world. In the "good" state, the interests of the relevant countries converge and those that comply with the agreeinent receive a payoff higher than if they had violated the agreement. As a result, all countries comply in this period and in each period thereafter. ${ }^{94}$ In the good state, then, countries behave in the same way whether there is an agreement or not, and international law does not affect the behavior of states.

If the countries find themselves in the "bad" state, however, they face a prisoner's dilemma. If there is no agreement in place, countries behave in a noncooperative fashion (they "defect" in game-theoretic parlance), and receive a corresponding payoff of 3 in this period and every period thereafter. Letting $r$ represent the discount rate-that is, the extent to which the country values benefits today over benefits later-each country receives a payoff stream of $3+3 /(1+r)+3 /(1+r)^{2}+\ldots=3(1+r) / r .{ }^{95}$ To simplify further, let $R=(1+r) / r$. We can then represent the payoff to each country as $3 R$. This is the realist result, presented in Figure $\mathrm{A}$ and the accompanying discussion, which leads to the conclusion that international law has no effect.

Reputation, however, can alter the above equilibrium. For simplicity, begin by assuming that countries will only enter into agreements with countries that have a good reputation. ${ }^{96}$ A good reputation is maintained as long as a country honors all of its previous international commitments. A country that has a good reputation stands to earn a payoff of 5 in the

assume that the proposed tariff would be permissible under the WTO.) The decision of whether to impose such a tariff, then, would be made based on the costs and benefits to the Umited States as a result of the tariff. In the presence of a trade agreement, however, the United States must also consider the consequences of violating the agreement. Suppose that the United States is, at the same time, trying to negotiated a Free Trade Agreement of the Americas ("FTAA"). A violation of NAFTA may harm its ability to obtain such an agreement because the countries involved, including Mexico, could come to doubt the willingness of the United States to honor its commitments. In deciding whether or not to adopt the proposed tariff, then, the United States must include in its calculus the cost of that action to its FTAA efforts.

93. State behavior may provoke reaction from other states even in the absence of a legal commitment. These may be sanctions for the failure to honor an inplicit commitment, or they may be a response motivated by some other, nonlegal concerns. See infra Part III.A.5.

94. For simplicity, it is assumed that the state of the world does not change after the first period.

95. The calculation of the payoffs is straightforward once it is recognized that $x+x /(1+r)+$ $x /(1+r)^{2}+\ldots=x(1+r) / r$.

96. For the moment it is assumed that countries have either a good reputation or a bad one. This is done to clarify the exposition and is not necessary for the theory, and the paper discusses infra both how reputation can vary along a spectrum and how a country's reputation may differ from one subject matter to another. See infra Part III. 
current period by complying with its international obligation, and a payoff of 5 in each future period (assuming that the other country also complies). If the state violates its commitment, while the other country complies, it earns 6 in the current period and three in each period thereafter. ${ }^{97}$ Thus, the country must choose between two possible payoff streams:

If it continues to comply: $\quad 5+5 /(1+r)+5 /(1+r)^{2}+\ldots=5 R$

If it does not comply: $\quad 6+3 /(1+r)+3 /(1+r)^{2}+\ldots=3+3 R$

Put another way, if an agreement is in place, "cheating" carries with it a reputational sanction. This is illustrated in Figure $C$, which represents the subgame in which the parties are in the bad state of the world and have a legal obligation. The payoff to a country that cheats, therefore, is $3+3 R$ if the other country complies and $3 R$ if the other country cheats. ${ }^{98}$ The payoff for a country that complies is $5 R$ if the other country complies and $3 R-1$ if the other country violates the law. ${ }^{99}$

Figure $\mathrm{C}$ demonstrates how the reputational effect of a violation alters the decision process. An equilibrium in which both countries comply in every period is sustainable in this game for a sufficiently low discount rate (corresponding to a sufficiently large $\mathrm{R}$ ). In other words, for a sufficiently low discount rate, a country will comply with its international obligation even when it would not have done so in the absence of that obligation. It complies in order to avoid the reputational loss that would come with a violation of international law.

Figure C

\begin{tabular}{|c|l|l|l|}
\multicolumn{1}{c}{} & \multicolumn{2}{c}{ Country 2} \\
\cline { 2 - 4 } & Comply & Violate \\
\cline { 2 - 4 } Country 1 & Comply & $5 \mathrm{R}, 5 \mathrm{R}$ & $3 \mathrm{R}-1,3+3 \mathrm{R}$ \\
\cline { 2 - 4 } & Violate & $3+3 \mathrm{R}, 3 \mathrm{R}-1$ & $3 \mathrm{R}, 3 \mathrm{R}$ \\
\hline
\end{tabular}

97. That is, it earns 6 in this period because the other party complies while it violates the agreement, but in each period thereafter there is no agreement in place, so both parties defect and the country earns 3 .

98. Note that because $R=(1+r) / r, \mathrm{R}$ is always greater than 1 .

99. The use of numbers in the above examples and throughout the Article should not be taken to imply that the calculation of costs and benefits takes place in an environment of great certainty. Because reputational sanctions (and, indeed, nonreputational ones) are uncertain, it is rarely the case that one can predict the precise consequences of an action. This fact does not, however, undermine the theory presented. It is the role of the decision-maker to assess these future costs and benefits before choosing a course of action. In more formal terms, the decision-maker uses the available information to determine the probability distribution of eosts and benefits. Based on that probability distribution, the expected costs and benefits can be determined. The subjective nature of this process is one reason why the identity of national leaders is important. 
Reputation, therefore, causes future relationships to be affected by today's actions. ${ }^{100}$ Accounting for reputational effects, a decision to violate international law will increase today's payoff but reduce tomorrow's. This explains not only why nations comply with international law despite the weakness of existing enforcement mechanisms, but also why they sometimes choose to violate the law. The existence of a reputational effect impacts country mcentives, but in some instances that impact will be insufficient to alter country behavior. So, unlike some existing theories of international law, this model reconciles the claim that international law affects behavior with the fact that the law is not always followed.

In the absence of other enforcement mechanisms, then, a state's commitment is only as strong as its reputation. When entering into an international commitment, a country offers its reputation for living up to its commitments as a form of collateral. ${ }^{101}$ The value of that collateral, of course, varies from country to country and may also vary depending on the identity of the country on the other side of the agreement. Thus, for example, a treaty between Canada and the United States benefits from a high level of reputation and trust. The two countries have a long history of cooperative dealings, and to violate a promise would have a negative effect on many other interactions. A treaty between the United States and Iraq, on the other hand, would enjoy a much lower level of reputational collateral. Iraq and Saddam Hussein are not considered reliable treaty partners, in large part because of earlier violations of international legal commitments. ${ }^{102}$

Because a country's reputation has value and provides that country with benefits, a country will hesitate before compromising that reputation. ${ }^{103} \mathrm{~A}$ country that develops a reputation for compliance with international obligations signals to other countries that it is cooperative. This allows the state to enjoy long-term relationships with other cooperative states, provides a greater ability to make binding promises, and reduces the perceived need for monitoring and verification. On the other hand, failure to live up to one's commitments harms one's reputation and makes future

100. The impact of direct sanctions are put to the side for the moment. These also increase the cost of violating international law and provide an additional incentive to comply.

101. See Keohane, supra note 65 , at 26 ("International regimes alter the information available to governments and the opportunities open to them; commitments made to support such institutions can only be broken at a cost to reputation. International regimes therefore change the calculations of advantage that governments make.").

102. The invasion of Kuwait is the most obvious such violation, but not the only one. The continued refusal to honor the terms of the peace agreement that followed the Persian Gulf War, the perception that Iraq has sponsored international terrorist activity, and earlier treaty violations such as the 1981 unilateral "cancellation" of the 1975 border agreement between Iran and Iraq all represent instances in which Iraq has shown itself to be an unreliable partner. See Political and Security Questions: Questions Concerning Iran, 1981 U.N.Y.B. 35, U.N. Sales No. E.84.I.1.

103. See Simmons, supra note 2, at 325 ("Governments comply with their legal commitments largely to preserve their reputation...."). 
commitments less credible. ${ }^{104}$ As a result, potential partners are less willing to offer concessions in exchange for a promised course of action. ${ }^{105}$

It is worth noting that the development of a strong reputation for compliance with international agreements is itself subject to a cost-benefit analysis by nations. If a country suffers a loss of reputation, it must rebuild its reputation by demonstrating a pattern of compliance with international law. If a country's reputation is sufficiently tarnished, of course, attempts to rebuild it may not be worthwhile. The development and destruction of a reputation occur over longer periods of time than do individual decisions regarding compliance with an obligation, but they are nevertheless the result of government decisions.

Nothing in the theory advanced in this Article suggests that all countries will want to preserve a reputation for honoring their commitments. Countries that decide against developing a strong reputation for compliance with international obligations choose short-term benefits over longterm gains. Those countries are more likely to ignore international commitments and, as a result, are less likely to find partners willing to rely on such commitments. In the extreme case, a country has zero reputational capital, and international law acts as an independent force only to the extent that it generates direct sanctions, as discussed in Part III.B.

Finally, when examined in all its dimensions, reputation need not always be a force toward compliance with international law. Nations prefer a reputation for compliance with international law so that they are able to make credible commitments in the future, but they are also concerned about other aspects of their reputation. A reputation of siding with allies

104. See Andrew T. Guzman, The Cost of Credibility: Explaining Resistance to Interstate Dispute Resolution Mechanisms, 31 J. Leg. STud. 303, 311 (2002).

105. For example, during the early negotiations prior to the Uruguay Round of trade talks, the United States and other western states faced resistance to the idea of expanding GATT's authority because those countries were not honoring their existing commitments. See RAY AugusT, INTERNATIONAL BUSINESS LAw 359 (2000). Similarly, when the United States government abducted Mexican citizens in violation of international law in the Alvarez-Machain incident, the negotiations of the NAFTA agreement were negatively affected. See United States v. Alvarez-Machain, 504 U.S. 655 (1992); Koh, Legal Process, supra note 47, at 203. In this example it may be the case that the reaction of Mexican authorities was a form of retaliation rather than a reaction to a change in the reputation of the United States. Even if this is true, however, reputation is in the background bccause Mexico retaliated due to misconduct by the United States to establish a reputation for such retaliation in the hope of influencing future behavior. For a discussion of Alvarez-Machain, see William J. Aceves, The Legality of Transborder Abductions: A Study of United States v. Alvarcz-Machain, 3 Sw. J.L. \& TRADE AM. 101 (1996); Andrew L. Strauss, A Global Paradigm Shattered: The Jurisdictional Nihilism of the Supreme Court's Abduction Decision in Alvarez-Machain, 67 Temp. L. Rev. 1209 (1994); Kristin B. Weissman, Comment, Extraterritorial Abduction: The Endangerment of Future Peace, 27 U.C. Davis L. Rev. 459 (1994); Manuel R. Angulo \& James D. Rearson, Jr., The Apparent Political and Administrative Expediency Exception Established by the Supreme Court in United States v. Humberto Alvarez-Machain to the Rule of Law as Reflected by Recognized Principles of International Law, 16 B.C. INT'L \& CoMP. L. REv. 245 (1993). 
can be valuable, as can a reputation for toughness. ${ }^{106}$ During the Cold War, for example, the United States sought to establish a reputation for adherence to a policy of containment of communism. Such forces can provide incentives either for or against compliance, depending on the circumstances. This observation does nothing to undermine the theory being advanced here, which seeks to isolate that aspect of reputation that is linked to compliance.

\section{An Application of the Model: Bilateral Investment Treaties}

The reputational theory of niternational law can be applied to a wide range of state behavior. For reasons discussed below, it predicts that international law will have a greater impact on economic matters than on inilitary and security matters. ${ }^{107}$ To illustrate how the theory can be applied to a specific topic, this Section discusses bilateral investment treaties ("BITs") and their effect on country behavior. ${ }^{108}$

Consider a country that has signed a BIT in which it promises not to expropriate foreign investment. ${ }^{109}$ Assume for the purposes of this exainple that the country makes this promise because doing so increases the flow of foreign direct nivestment into the country. ${ }^{110}$ Even after making the promise, of course, the country could choose to expropriate the local assets of foreign firms. Assume that the available assets have a total value of $\$ 100$ million to the country. This potential gain of $\$ 100$ million must be weighed against the cost of an expropriation, which includes several components. First, the violating country loses the benefits currently being provided by foreign firms, including tax revenues, technological transfers, employment, and so on. ${ }^{111}$ Suppose that this loss amounts to $\$ 40$ million. ${ }^{112}$ Second, the

106. See Keohane, supra note 91, at 497; Benedict Kingsbury, The Concept of Compliance as a Function of Competing Conceptions of International Law, 19 MiCH. J. INT'L L. 345, 352-53 (1998).

107. See infra Part IV.D.

108. For a detailed discussion of BITs, see Guzman, supra note 56, at 654-58; Kenneth J. Vandevelde, U.S. Bilateral Investment Treaties: The Second Wave, 14 Mich. J. INT'L L. 621 (1993).

109. Other examples could obviously be chosen here. BlTs are selected because the costs and benefits are more easily understood and evaluated in the context of such treaties than in many other examples. It is important to note, however, that difficulties expressing costs and benefits in dollar terms do not represent a problem for the theory presented.

110. The expropriation of foreign-owned assets occurred numerous times in the twentieth century. Some examples include: the Mexican expropriation of agrarian and oil properties between 1915 and 1940; the Soviet expropriations following the Russian revolution; the Egyptian expropriations that led to the Suez crisis; Cuban expropriations following the rise to power of Fidel Castro; the taking of partial ownership in copper mines in Chile in 1971; and expropriations by Iran following the fall of the Shah. See Charles Lipson, Standing Guard, Protecting Foreign Capital in the Nineteenth AND Twentieth Centuries (1985); F.N. Burton \& Hisashi lnoue, Expropriations of Foreign-Owned Firms in Developing Countries, 18 J. World TRAde L. 396 (1984); Detlev F. Vagts, Foreign Investment Risk Reconsidered: The View from the 1980s, 2 FoREIGN 1Nv. L.J. 1 (1987).

111. It is true that the expropriating country may be able to generate some of these benefits by continuing to operate the expropriated firms. Unless the government can operate the firms as efficiently 
country is likely to suffer a reputational loss in the eyes of foreign investors. The act of expropriation signals a willingness to seize the assets of foreigners and reduces the attractiveness of the country to potential investors. Assume this translates into a loss of future investment, which the country values at $\$ 40$ million. Finally, the country will suffer a loss of reputational capital with respect to other countries. Potential treaty partners will view the country as a less reliable partner and will be less willing to enter into future agreements. Assume that this loss is equivalent to $\$ 30$ million. Taken together, then, the total $\cos ^{113}$ of the expropriation will be $\$ 110$ million.

In deciding whether or not to violate its international commitment, a country compares the total costs of doing so to the total benefits. Using the numbers given above, it is clear that the country would prefer to honor its commitment. A violation of the treaty would impose a loss of $\$ 110$ million and yield a gain of only $\$ 100$ million-a net loss of $\$ 10$ million. Notice also that the outcome can change as a result of international law. In the absence of a legal obligation, the expropriating country would not suffer a $\$ 30$ million reputational loss in the eyes of other states, so its total loss from the expropriation would be no more than $\$ 80$ million. Because the benefits from expropriation are $\$ 100$ million, the expropriation would cause a net gain absent the international commitment. ${ }^{114}$ This example demonstrates that a reputational loss can affect decisions even when the loss is considerably less than the total potential gains from the action. This is so because there will typically be other costs that the country must consider. This simply illustrates that the reputational consequences of an

and introduce the innovations as quickly as the former owners could, however, the expropriation involves some loss.

112. All of the costs and benefits in this example should be treated as the present discounted value of the lost future stream of revenue.

113. Notice that only a portion of the above costs can be attributed to international law. Some benefits are lost due to existing foreign firms that either stop operating or operate less effieiently after expropriation, but are not affected by the country's legal commitments. In the eyes of other states, the reputational loss results from a violation of an international obligation. The country's act of expropriation in the face of a treaty expressly promising not to do so demonstrates that country's willingness to violate international commitments. Other countries will take this into account when dealing with the country. Finally, the reaction of potential foreign investors is partially, though not entirely, a function of the existence of international law. Even in the absence of an international legal commitment (putting aside, for simplicity, the fact that there may be a rule of CIL that prohibits expropriation without full compensation), a decision to expropriate will have a chilling effect on future investments. To the extent that investors view the legal obligation contained in the BIT as a credible commitment, however, the country becomes more attractive to investors and may enjoy higher levels of investment. If expropriation undermines this confidence, a portion of the lost investment can be attributed to a reputational effect resulting from the violation of international law.

114. Strictly speaking, one should include the fact that the BIT caused an increase in investmentmeaning that absent a BIT, the country would have less investment to begin with, reducing the attractiveness of expropriation. This detail can easily be added to the above example without changing the results. It is omitted only for simplicity. 
action can alter the outcome if they are large enough to tip the balance of costs and benefits in favor of compliance.

If we make different assumptions about the numbers, of course, we can generate different results. For exainple, if the gain from expropriation is $\$ 200$ million while the other numbers are unchanged, the country will choose to expropriate, even if doing so is a violation of international law.

\section{Dynamic Issues}

A country's decision to follow international law reflects a judgment that the costs of a violation outweigh the benefits. Because the opportunities and risks facing a country vary both over time and across contexts, however, a country may choose to follow a particular law at one time or in one context and violate it at another time or in another context.

This dynamic aspect of compliance with international law can be illustrated with the BIT example from the previous Section. Suppose a country anticipates that the expropriation of foreign investment will lead to a coinplete halt in the flow of investment into the country. ${ }^{115}$ Assume that the expropriated investment is worth $\$ 100$ million to the country if left in the hands of investors and $\$ 200$ million if expropriated. The benefit from expropriation, therefore, is $\$ 100$ million. To evaluate the cost of the expropriation, the decision-makers must also consider the value of future investment if it expropriates (which by assumption is zero) as compared to the value of future investment if it does not expropriate. If the expected value of future foreign investment changes over time, a country may choose to abide by its BITs for a period of time but, when conditions change, it inay decide to violate those commitments.

Imagme that times are good and the country is enjoying high levels of foreign investment that are expected to increase further in the years to come. The present discounted value of future investment is $\$ 200$ million. Under these conditions, expropriation is unattractive. The country can do better by encouraging more foreign investment and by treating that investment well. Benefits in the form of tax revenues, employment, technology transfers, and so on, are larger than the benefits from expropriation. Now suppose that the political mood in the country changes as the leader of a populist party gains widespread support by blaming the country's troubles on foreign capitalists. He points to the high level of foreign investment in the country and the substantial profits being made by investors, contrasting this with the low wages paid at some of the facilities of foreign firms. His actions generate feelings of hostility toward foreign interference in the local economy, and newly formed rebel groups target foreigners for kidnapping. Suppose further that despite its best efforts, the

115. This extreme assumption is used to make the illustration clear. It is not necessary for the results. 
government cannot provide sufficient security to ensure the safety of all foreign residents and businesses.

From the perspective of a potential investor, these developments greatly reduce the country's appeal. Not only are employees at risk, but there is no way of knowing if the current pro-investor regime will win the next election or if the country will be consumed by violence and possibly even civil war. As a result of these events, the expected level and value of future investments fall to the point where the expected streain of benefits to the country is worth, say, $\$ 50$ million rather than $\$ 200$ million. This lower level of expected future investment affects the country's expropriation decision. The country still stands to gain $\$ 200$ million by expropriating, as compared to $\$ 100$ million from existing investment plus $\$ 50$ million from future investment if it does not expropriate. The reduction in future investment has made expropriation the country's best strategy. ${ }^{116}$

The same dynamic analysis applies in every case in which the present value of some future benefit changes based on the country's present choices. For instance, the history of Russian and Soviet debt in the twentieth century demonstrates exactly this sort of behavior. When the Soviet Union came into being, it immediately repudiated debts from the prior Russian czarist regime. ${ }^{117}$ The political philosophy of the new Soviet Umion was hostile to the established sources of capital. Therefore, it stood little chance of securing large foreign loans in the foreseeable future. ${ }^{118}$ In that environment, a refusal to pay is easy to understand because the country had little to lose by offending international capital markets. When the Soviet Union collapsed, however, the situation changed. The new Russian government was in need of large capital infusions, including loans from other states and the International Monetary Fund. In an effort to improve its reputation among potential creditors, the Russian state pledged to repay not only Soviet debts, but also to compensate the holders of Russian bonds repudiated by the Soviet Union in $1918 .{ }^{119}$

\section{E. The Level of Commitment}

The above discussion demonstrates that a model of rational states is consistent with the existence of international law. This result is important

116. A country's compliance decision may, in an analogous way, also vary depending on the context. For example, a country that has BITs with two different partners may choose to violate one treaty but not the other if the gains from violating the first are larger than the costs while the costs outweigh the benefits in the case of the second treaty.

117. Barry Eichengreen \& Richard Portes, Debt and Default in the 1930s: Causes and Consequences, 30 Eur. ECON. Rev. 599, 613 (1986).

118. The United States did not even recognize the Soviet government until the 1933 Litvinov Assignment. See United States v. Pink, 315 U.S. 203 (1942).

119. Uli Schmetzer, Russia to Pay Off Old Bond: After 78 Years, the Czar's Markers Are Worthless No More, CHI. TriB., Nov. 28, 1996, at 1. 
because, just as the ability to bind oneself through contract is valuable to private parties, the ability to commit to a particular action is valuable to states. A state's ability to signal its commitment more credibly through an international agreement, whether a treaty or other form of promise, increases welfare because it allows that state to enter into a broader range of potential agreements. In other words, the ability to make credible commitments makes states better off. ${ }^{120}$

In the absence of transaction costs, the parties to an agreement would specify the precise conditions under which they would (or would not) perform. Agreements would list every possible state of the world and the obligations of the parties in each state. ${ }^{121}$ As events unfolded, one could simply refer to the contract to identify the obligations of each party. By specifying the precise conditions under which they plan to perform, states could also specify the conditions under which they would refuse performance. The agreement itself would excuse performance in some situations, and a country could make agreements that it would never violate. If such agreements were possible, there would be no reason for the many different types of international commitments. Rather than signing a nonbinding agreement, for exainple, a state could simply specify the conditions under which it promises to carry out the requirements of the treaty and those under which it does not. The agreement could then be included in a binding treaty under which one or both parties would be excused from performance in certain circumstances.

In practice, however, substantial transaction costs prevent international agreements from specifying every possible future contingency. First, it is often inpossible to predict all potential future states of the world, let alone to list them all $\mathrm{m}$ an agreement. For example, in the mid-1980s it would have been difficult to predict the collapse of communism and the subsequent evolution of Eastern Europe and the former Soviet Union to Inarket-based economies with democratic governments. Second, even if the range of possible states of the world is known, the probability of being in any given state of the world is not. For example, it is conceivable that a Free Trade Agreeinent of the Americas will be signed within the next ten years, but the probability of such an event is difficult to estimate. Third, identifying the state of the world at any given moment is difficult. Countries may disagree, for example, about whether certain practices constitute protectionist barriers or reasonable health measures, and this introduces

120. The value of a good reputation for states can be compared to the value of a high bond rating. Just as a good rating increases investor confidence and, therefore, allows the firm to raise money more cheaply, a strong reputation increases the confidence of counterparties to an international agreement, allowing a state to extract more in exchange for its own promises.

121. Notice that a complete specification of terms in this way would allow countries choosing to develop reputations for honoring their commitments to make agreements that are fully specified and that make it unnecessary to ever violate their obligations. 
questions of interpretation that can lead to a dispute even in the case of a well-specified treaty. Finally, a long list of contingencies and conditions can make ratification of international agreements much more difficult. Even where an agreement taken in its entirety is a good one, groups opposed to it would still have ammunition with which to rally public opinion in opposition. ${ }^{122}$

As a result of these and other transaction costs, international agreements do not list every possible contingency. The parties to an agreement know that reservations, exceptions, escape clauses, and so on capture only some of the possible future situations. They recognize that there is a risk that they will violate a commitment, and that this may generate a loss of reputation. Consequently, a country that wants to make a promise, but recognizes a high probability that it will later violate that promise, may not want to put too much of its reputation on the line. Of course, if the reputational risk is too great, a country can always choose simply not to make the promise. This strategy is not ideal, however, because the country may want to make at least a weak promise to extract some form of concession from the other side.

Having the ability either to commit or not commit is valuable, then, but the ability to choose from a range of commitment levels is even more valuable. By varying the form of its promise, a state can choose its level of commitment and signal that commitment to other states. ${ }^{123}$ Suppose that a country is willing to share certain information regarding Internet-fraud schemes in exchange for a reciprocal promise of information sharing. The state may be concerned, however, that privacy issues will arise, become important to its citizens, and force the state to end the practice of sharing information. The treaty could expressly address this contingency, but the state may also be worried that other unanticipated or unforeseeable developments will make the country want to violate its promise. In this example, because violating a treaty carries reputational costs, a treaty may represent an excessive commitment. However, simply refusing to enter into any agreement frustrates the country's initial goal. The best solution, then, may be an intermediate level of commitment, which could take the form, for example, of an "accord" that falls short of a treaty but that specifies the commitments of each state. ${ }^{124}$

122. In some circumstances an agreement will, in fact, not be in the national interest. In those cases, the ability to oppose its ratification may be good for a country. Those who draft an agreement, however, almost always want the agreement to be adopted. Because they determine the level of detail included in the treaty, they are able to keep the agreement simple and improve its chances of adoption.

123. See Charles Lipson, Why Are Some International Agreements Informal?, 45 INT'L ORG. 495 , 508 (1991) (stating that countries use treaties to "signal their intentions with special intensity and gravity ....").

124. See Guzman, supra note 104 (explaining with a similar argument why states who enter into a treaty may not always want a dispute-settlement provision). 
It is possible to identify at least two dimensions along which international agreements can range in order to adjust the level of commitment: (1) the formality of the commitment and (2) the clarity of the agreement. When possible, countries that wish to increase the level of commitment prefer more formal and detailed agreements. For example, trade negotiations often feature schedules of commitments that provide a precise enumeration of commitments and obligations. ${ }^{125}$ At the other extreme, vague statements regarding national intent lead to relatively low levels of commitment, in part because it is difficult to determine when a country has violated the agreement. ${ }^{126}$

The ability to modulate the level of obligation should not be mistaken for a system of truly enforceable promises. By choosing one form of international agreement over another, countries are varying the reputational stake that they have in the obligation. A violation will impose a higher reputational cost in the case of a treaty than it will in the case of a nonbinding agreement. In neither case should one conclude that the country cannot turn away from its obligation. The strength of reputation remains limited, and even the strongest commitments will sometimes be ignored. On the other hand, it is a mistake to discount the importance of reputation altogether. As discussed in Part II.B, a reputation for compliance with agreements is valuable to a country, so countries will only compromise that reputation if they receive something else of higher value in exchange. ${ }^{127}$

\section{F. International Law and Coordination}

When states cooperate to resolve straightforward coordination games, it is fair to say that international law plays a limited role. Imagine, for example, that two countries wish to shut down an international organized crime syndicate. By cooperating, the countries stand a good chance of success, so assume they each receive a payoff of 5 . A single country acting alone stands little chance of succeeding, yielding an expected loss of 3 . Further, a state that ignores the syndicate while the other state pursues it can divert resources to other concerns while still enjoying some chance that the syndicate will be hampered, yielding a payoff of 3 for the passive country. Finally, both countries could ignore the syndicate and endure the associated crime, which will free resources to combat other problems; this generates a gain of 2 for each country. Figure $D$ represents this game.

125. See, e.g., NAFTA, supra note 92.

126. See Kal Raustiala, Form \& Substance in International Agreements (2002) (unpublished manuscript, on file with author).

127. See Lipson, supra note 123, at 511. 
FIGURE D

\begin{tabular}{|c|c|c|c|}
\hline & \multicolumn{2}{|c|}{ Country 2} \\
\hline & & Pursue & Ignore \\
\hline \multirow{2}{*}{ Country I } & Pursue & 5,5 & $-3,3$ \\
\hline & Ignore & $3,-3$ & 2,2 \\
\hline
\end{tabular}

In equilibrium, the countries will reach an agreement in which each promises to pursue the syndicate. Once they reach such an agreement, neither country has an incentive to violate its commitment, and no threat of sanction is needed to achieve cooperation. Furthermore, the form of the agreement is not terribly important. The countries could sign a treaty agreeing to pursue the crime syndicate, but a treaty is not necessary. It would be equally effective to reach an informal agreement between the countries or between the relevant law-enforcement agencies. In fact, a similar outcome could be reached without any agreement between the parties. ${ }^{128}$ Because this game is resolved through simple coordination and without the need for sanctions, one can question whether this is an example of international law at all. ${ }^{129}$ Although international law may serve to focus the interaction on a single outcome where several equilibria exist, it does little else. ${ }^{130}$

If one adopts a more realistic model of a coordination game, however, international law can play a significant role. There are at least two extensions of the simple coordination game that make international law relevant. First, the parties may not know one another's payoffs with certainty. In that situation, even if the actual payoffs are as indicated in Figure D, the countries may not be certain that coordination is sufficient to ensure the desirable outcome. Country 1, for example, may mistakenly believe that the payoffs are as shown in Figure E rather than Fignre D.

FIGURE E

\begin{tabular}{|c|l|l|l|}
\multicolumn{1}{c|}{} & \multicolumn{2}{c}{ Country 2} \\
\cline { 2 - 4 } & Pursue & Ignore \\
\cline { 2 - 4 } Country 1 & Pursue & 5,5 & $-3,6$ \\
\cline { 2 - 4 } & Ignore & $3,-3$ & 2,2 \\
\cline { 2 - 4 } & Igere &
\end{tabular}

128. It would be sufficient for one country to declare its intention of pursuing the crime syndicate in a public and credible way by, for example, expending funds to do so. The other state, seeing that the first state was pursuing the syndicate, would have an incentive to do the same.

129. See Goldsmith \& Posner, supra note 5, at 1127-28.

130. The resolution of coordination games is one explanation for informal agreements among states. Because coordination games need only a focal point in order to achieve the desired equilibrium, there is no need for a formal and detailed agreement. Once the focal point is identified, no state has an incentive to "cheat." 
Such mistaken beliefs will affect a country's decision to enter into a legal agreement to combat the syndicate. If Country 1 believes that Figure $\mathrm{E}$ represents the payoffs, it will expect Country 2 to ignore the syndicate. In this situation, Country 1 will not expect mere coordination to be sufficient to ensure that both countries pursue the syndicate. As a result, Country 1 will not pursue the syndicate unless it has some assurance that Country 2 will do the same. If the parties sign a treaty pledging to pursue the crime syndicate, the reputational cost of a failure to do so may be enough to make Country 2's promise credible to Country 1 . If so, both countries will sign the treaty and pursue the syndicate. The lesson here is that if the payoffs are not common knowledge, international law may help achieve the valuemaximizing outcome in a coordination game.

A second extension of the basic coordination game recognizes that circumstances change over time. 1magine, for example, that in the first period everybody expects that in the second period the crime syndicate will concentrate its operations in one state. Once the syndicate has turned its focus to one of the countries, the other has no incentive to pursue it. Nobody knows, however, which state will face a growth in activity and which will witness a decline. Because neither state is likely to succeed in controlling the syndicate alone, both are willing to commit to a cooperative effort to defeat the syndicate in the future rather than risk being the focus of its activity.

In this example, both states are better off ex ante if they are able to commit to a joint crime-fighting effort, but once the uncertainty is resolved, one state will have an incentive to ignore the syndicate. Both states, therefore, prefer to commit to working together in period one, but once the uncertainty is resolved, one of them will have an incentive to ignore that commitunent.

FIGURE F

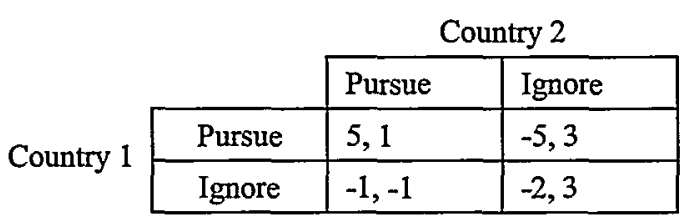

If commitment is not possible the period-two payoffs are those given in Figure $F$, which assumes that the crime syndicate concentrates its efforts in Country 1 . If both countries pursue the syndicate, Country 1 gains 5 , just as in Figure E. Country 2, however, gains only 1 because the crime syndicate's activities in Country 2 have been reduced, making a successful crime-fighting effort less valuable than it is in Figure E. If both countries ignore the syndicate in period 2, Country 1 suffers a loss of 2 as a result of the crime. Country 2, however, enjoys a gam of 3 because it can devote its 
resources to other priorities. If only Country 1 pursues the syndicate, it suffers a loss of 5 because it is unlikely to succeed in defeating the syndicate, and it uses up valuable resources trying to do so. Country 2 once again gains 3 . Finally, if only Country 2 pursues the syndicate, it receives a payoff of -1 because it uses up resources, and Country 1 receives a payoff of -1 because it suffers from the crime but can at least use resources in other areas. Consequently, regardless of what Country 1 does, ignoring the crime syndicate is a dominant strategy for Country 2. Knowing this, Country 1 will also choose to ignore the syndicate, and we end up with payoffs of -2 for Country 1 and 3 for Country 2.

If international law allows the countries to commit to a particular course of action, however, they can agree in the first period to pursue the syndicate. ${ }^{131}$ This result maximizes the payoffs to the countries. The point here is that although international law has little role to play in a pure coordination game, the dynamics of international relations may cause countries to enter into formal agreements even when they appear to face a simple coordination game. Incomplete information and changes in circumstances can turn a coordination game into a game in which the ability to commit to a particular course of action has value. Even when the game at hand appears to be a coordination game, therefore, there may be reasons to make use of international law and the ability to pledge reputational capital.

\section{III \\ VIOLATION AND COMPLIANCE}

An important benefit of a rational-actor model of international law is its ability to provide predictions about when countries will choose to violate international legal obligations. The decision to honor or breach a promise made to another state imposes costs and benefits upon the promisimg country and its decision-makers. The model assumes that decision-makers behave in such a way as to maximize the payoffs that result from their actions. ${ }^{132}$ Thus, where the benefits of breach outweigh its costs, a country is expected to violate its agreements with other states. International law succeeds when it alters a state's payoffs in such a way as to achieve compliance with an agreement when, in the absence of such law, states would

131. It is assumed that a commitment at period one is sufficient to achieve compliance-meaning we assume the reputational cost of a violation is large enough so that Country 2 will prefer to honor its commitment.

132. As previously mentioned, the precise set of payoffs that an actor maximizes need not be the one that maximizes the country's payoff; it may instead be the one that achieves the leader's personal objectives. Decision-makers whose goals differ from those of their countries may be more likely to violate international law because they do not bear the entire cost of such a violation. Such a situation would generally reduce the relevance of international law, but it does not present a problem for the theory presented in this Article. 
behave differently. ${ }^{133}$ In other words, international law succeeds when promises made by states generate some compliance pull. On the other hand, even when international law affects a state's payoffs, the costs of compliance will sometimes outweigh the benefits. This Part considers why and when states violate their international commitments, some of the factors that influence the magnitude of reputational sanctions, the role of direct sanctions, and when sanctions are most likely to be effective in encouraging compliance.

\section{A. Reputational Sanctions}

To generate prcdictions about state behavior, one must have a theory about the magnitude of the reputational loss resulting from violations of law. ${ }^{134}$ It seems clear that the reputational impact of a violation of international law varies depending on the nature of the violation. For example, a failure to comply with a mmor international obligation that is a result of oversight or human error and that is promptly corrected without damage to other states is unlikely to have a major reputational impact. In contrast, an egregious and intentional violation, such as support of terrorist activities against another state, is likely to have a profound impact on a nation's reputation. ${ }^{135}$

A list of factors that influence the reputational impact of a violation, therefore, should include (1) the severity of the violation, (2) the reasons for the violation, (3) the extent to which other states know of the violation, and (4) the clarity of the commitment and the violation. ${ }^{136}$ The following discussion outlines these factors as well as the possibility that states will suffer a reputational loss when they violate implicit obligations, and the impact of regime changes on reputation. ${ }^{137}$

\section{Severity of the Violation}

The reputational consequence of a violation is most obviously affected by the severity of that violation. A minor technical violation will have a small impact compared to a major violation of an international

133. Notice that in contrast to the domestic context, most international law cannot hope to achieve optimal deterrence. In most cases all that can be hoped for is a movement in that direction. Conditions that can promote optimal deterrence are discussed in Part II.C.

134. See George W. Downs \& Michael A. Jones, Reputation, Compliance, and International Law, 31 J. LeGal. STUd. S95 (2002).

135. Although this Article tends to speak of "a state's reputation," it is important to keep in mind that the reputation of a state may vary from one issue area to another and may depend on the identity of its counterparty.

136. This list is not intended to be exhaustive. Other factors may also be relevant.

137. The level of commitment taken on by a state is not discussed below because it is addressed in detail in Part II.E. 
obligation. ${ }^{138}$ Related to the severity of the violation is the magnitude of the harm suffered by other states. A violation that causes substantial and widespread harm does greater damage to a state's reputation than does a "victimless" violation or one that imposes only slight harms.

Consider, for example, the impact of violating the territorial waters of another state. If ships of one state sail through the waters of another in disregard of a policy requiring permission for such voyages, international law has been violated. ${ }^{139}$ If those ships simply pass through the waters without causing harm, the violation is unlikely to have major reputational consequences. ${ }^{140}$ If, on the other hand, the ships in question are fishing vessels that catch fish in the other state's waters, the consequences are likely to be greater. The impact on the offending state's reputation is greater still if the harm is felt by more than one country. It may be the case, for example, that the relevant waters for fishing purposes cross national boundaries. ${ }^{141}$ If this is so, by fishing in the waters of one country, the offending state is harming all countries whose fishing industries might be affected.

\section{Reasons for the Violation}

The reason for a violation of international law may also alter the magnitude of the resulting reputational loss. When entering into an agreement, states hope that their counterparty will honor its obligations. They also recognize, however, that compliance with international obligations is imperfect and that violations occur. It is understood that under certain conditions a state will choose to ignore its obligations. For example, violation of a human-rights treaty is viewed in a different light when it takes place under conditions of great national crisis than if the violation occurs during a period of normalcy. ${ }^{142} \mathrm{~A}$ state that breaches such a treaty in time of crisis may be able to retain a reputation for compliance with treaties during normal times. When normalcy returns, and the state seeks to participate in further human-rights negotiations, its reputation may not be unduly compromised.

\section{Knowledge of the Violation}

The extent to which a violation is known by the relevant players affects the reputational consequences of the violation. Obviously, if a violation takes place, but no other state has knowledge of it, there is no

138. See ChAYES \& CHAYES, supra note 4, at 18 ("Flouting a cease-fire under a peace agreement or refusing to allow inspection of nuclear reactors under the NPT would be expected to evoke very different responses from a failure to meet the reporting requirements of an environmental treaty.")

139. For simplicity and clarity, assume that the ships in question are owned by the state.

140. Repeated violations of this type may have greater consequences.

141. For example, the northeast coast of the United States represents a fertile fishing ground that is shared with Canada in the sense that the fish inhabit an area that crosses the Canada-U.S. boundary.

142. Note that this is a claim about how nations view a violation, not how traditional conceptions of international law view it. 
reputational loss. The reputational consequences will also be less if only a small number of countries know of the violation. For example, if the ships of one country fish in the waters of another, but only the offended country becomes aware of the incident, the offending country may only suffer a reputational loss in the eyes of that other country. As no other country knows of the violation, there is no loss of reputation with respect to those countries. Even if the county who suffered the violation attempts to publicize it, the offending country may be able to deny the accusations in a credible fashion. This represents part of the reason why states expend resources to deny alleged violations of international law. To the extent that the accused party is able to convince others that it has done nothing wrong, the reputational harm is reduced.

\section{Clarity of the International Obligation and Its Violation}

An issue closely related to the question of states' awareness of a violation of international law is the matter of clarity. The clarity of both the international obligation and its violation are important because a failure to live up to an international obligation triggers a reputational loss. The reputational consequences are most severe when the obligation is clear and the violation is unambiguous. As the uncertainty of an obligation increases, the reputational cost from a violation decreases.

The inverse relationship between the reputational cost of a violation and the certainty of that violation may explain why battles over the content of CIL are fought. If the existence of a rule of customary law is in doubt, the reputational cost of a violation will be smaller. Thus, for exainple, debates over the role of CIL in human rights issues can be explained by the desire of each side to control the content of CIL. If a particular humanrights issue is dceined a CIL norm, states that violate the rule will pay a higher reputational price for doing so.

\section{Implicit Obligations}

Because reputation plays a central role in compliance decisions, one must consider the possibility that a state may suffer a reputational loss for actions that are consistent with its explicit international obligations. That is, the actions of states may create implicit commitments in addition to the explicit ones listed in an agreement. If they do, violation of these implicit promises may also lead to a loss of reputational capital. Putting aside the semantic question of whether it makes sense to call such actions violations of law, their reputational consequences may affect state behavior.

Imagine that the United States announces an intention to withdraw from NAFTA, consistent with the withdrawal provisions of the treaty which allow any party to withdraw "six months after it provides written 
notice of withdrawal to the other Parties."143 Though the United States would not be violating international law, Canada and Mexico, having undergone a period of economic dislocation and adjustment following the adoption of NAFTA, and having made plans-in both the private and public sectors-that rely on NAFTA's continued existence, are sure to suffer losses as a result of the U.S. decision. Although the countries did not explicitly commit themselves to NAFTA for more than six months, each country may believe that there is an implicit promise to honor the treaty for a longer period. At a minimum, one would expect that an American withdrawal from NAFTA would dampen enthusiasm in Canada and Mexico for further trade agreements. In other words, withdrawal from NAFTA could impose reputational costs on the United States that resemble (though perhaps on a smaller scale) those imposed by a violation of the treaty. ${ }^{144}$

Furthermore, a country may suffer a reputational loss as a result of actions contrary to the terms of an agreement to which it is not a party. For example, the Basle Accord establishes minimum capital-asset ratios for banks. ${ }^{145}$ The Basle Accord enjoys widespread compliance, not only among signatory countries, but also among countries that did not sign and were not involved in the negotiations. ${ }^{146}$ Imagine that Country A chooses to comply with the Basle Accord, even though it was not a signatory. If, after several years of compliance, it changes its policies and decides to ignore the Basle Accord, it might suffer a reputational loss. While Country A was in compliance, other countries may have assumed that it would continue to comply, and may have adjusted their policies in reliance.

\section{Regime Changes}

The above discussion treats each state as an entity that would be permanently tainted by a violation of international law. Because the passage of time reduces the reputational consequences of any particular act, and because a state may be able to neutralize the reputational consequences of prior actions through a change in leadership, this notion of "permanent taint" is clearly an overstatement. Imagine, for example, that a government continually ignores its international commitments as part of a domestic political platform of isolation and independence. The government will most likely be unable to obtain concessions from other states in exchange

143. NAFTA, supra note 92, art. 2204.

144. This example demonstrates the difficulty of distinguishing legal commitments from international relations in general. A country that habitually enters into international obligations only to withdraw shortly thereafter is a less-desirable partner, regardless of whether or not the withdrawals are consistent with the terms of the agreements. Violations of explicit commitments may be more costly in terms of reputation than violations of implicit commitments, but both kinds of action come with a reputational price tag.

145. See Charles W. Hultman, Foreign Banks and the U.S. Regulatory Environment, 114 BANKING L.J. 452, 455 (1997).

146. Id. 
for its own promises. If that government falls and is replaced by another that openly favors closer ties with the outside world, compliance with international legal obligations, and openness, the reputational impact of the past policies may be partially or even entirely erased.

During the early 1970s, the Allende regime in Chile began to expropriate foreign investment, and conditions were generally unfavorable to foreign investors, with the predictable result that foreign investment fell virtually to zero. Although some of the investment decisions were surely based on pessimism about the Chilean economy, some were based on concerns about the potential for future expropriations. Following the successful coup by Pinochet, however, foreign investment returned in short order. By 1975 , the flow of foreign investment reached $\$ 50$ million, the first time in the decade that it was positive. By 1978, foreign investment was $\$ 181$ million. Some of the increased inflow must be attributed to the more favorable economic climate for investment created by Pinochet's regime. Nevertheless, it is clear that the reputational concerns that arose as a result of expropriation and other acts under Allende's reign largely disappeared when Pinochet rose to power.

The ability of a new regime to avoid the reputational stigma of past state-sponsored actions will depend a great deal on the particular circumstances of the case. If the new adininistration is perceived to be ideologically similar to prior ones, it will probably be difficult to shed a negative reputation. In addition, if the former regime is likely to regain power in the near future, its reputation will contimue to affect the behavior of other states.

\section{B. Direct Sanctions}

Up to this point, this Article has focused on the reputational impact of violations of international law, which is a markedly different approach from the way one ordinarily studies domestic rules. In the domestic setting, state-imposed sanctions receive the primary focus, while reputational effects, if any, are normally considered secondary. ${ }^{147}$ The weakness of direct sanctions in the international arena, however, makes reputational sanctions more important. That is not to say that direct sanctions are irrelevant.

147. In recent years there has been a renewed interest in the question of how social norms, including reputational sanctions, affect behavior. See ROBERT C. ElLICKSON, ORDER WiTHOUT Law: How Neighbors SetTle Disputes (1991); Eric A. Posner, Law and Social Norms (2000); Symposium, Law, Economics, \& Norms, 144 U. PA. L. Rev. 1697 (1996); Symposium, Social Norms, Social Meaning, and the Economic Analysis of Law, 27 J. LeGal STUD. 537 (1998); Lisa Bemstein, Opting Out of the Legal System: Extralegal Contractual Relations in the Diamond Industry, $21 \mathrm{~J}$. LEgAL STUD. 115 (1992); Robert Cooter, Normative Failure Theory of Law, 82 CoRNELL L. REv. 947 (1997); Steven Hetcher, Creating Safe Social Norms in a Dangerous World, 73 S. CAL. L. Rev. 1 (1999); William K. Jones, A Theory of Social Norms, 1994 U. ILL. L. Rev. 545; Jody S. Kraus, Legal Design and the Evolution of Commercial Norms, 26 J. LEGAL STUD. 377 (1997). 
In certain instances they can have an important impact on a country's incentives and behavior. This Section examines direct sanctions and discusses when they are likely to be most effective.

If states face direct sanctions for violations of international law, optimal compliance is more likely because reputational sanctions are generally, though not always, weaker than optimal sanctions. Just as compliance with a contract is not always optimal, $100 \%$ compliance with international law is not the optimal level of compliance. Like individuals entering into contracts, states entering into agreements are unable to anticipate all possible situations in their agreements, and in certain circumstances the total costs associated with compliance outweigh the costs of violation. Violation of the law is preferable in these cases. This point is understood in contract law, where it is well established that expectation damages encourage "efficient breach."148 The same result holds in international law. When the total benefits of a violation of international law outweigh the benefits of perfornance, it is preferable that there be a violation. ${ }^{149}$ Consequently, a regime under which violations of international law trigger expectation damages will lead to violations only when they are efficient. In other words, expectation damages lead to optimal levels of deterrence. ${ }^{150}$

Although direct sanctions could take a variety of forms, they most commonly consist of retaliatory measures taken by one or more states against a violator. For example, following the enactment of the Hawley-Smoot Tariff Act of 1930, which increased U.S. tariffs dramatically, other countries retaliated with tariff increases of their own. ${ }^{151}$

In some cases, direct retaliation takes the form of a decision by the complying state to terminate its own compliance with the underlying agreement. These types of retaliation often have the advantage of imposing a cost on the offending state and being in the interest of the complying state. ${ }^{152}$ Whether a complying country will resort to this form of retaliation

148. See Polinsky, supra note 86 , at 31 . In other words, if courts adopt expectation damages, contracts are breached if and only if breach is the value-maximizing outcome.

149. This is not meant to suggest that there is any simple way to aggregate the interests of states to determine when the benefits of a violation outweigh the costs. The point is simply that this will be true in some circumstances, implying that infinite sanctions for violations of the law are inappropriate.

150. Note that the damages referred to here include reputational loss. For this rcason, even if there were a mechanism to impose, say, monetary sanctions, it would be appropriate for these to be somewhat less than the level of expectation damages so that total damages, including both reputational and direct sanctions, do not overdeter breach. See infra note 170.

151. See Thomas D. Grant, Foreign Takeovers of United States Airlines: Free Trade Process, Problems, and Progress, 31 HaRv. J. ON Legis. 63, 139-40 (1994).

152. For example, imagine that Country A and Country B agree on the implementation of pollution controls in border areas. Assume that neither country would implement the controls by itself, but each is willing to do so to get the controls imposed by its neighbor. Suppose that Country A violates the agreement by failing to properly monitor and enforce the new controls. Country B may react by refusing to continue its own compliance with the agreement. This is a likely reaction by Country B because, by assumption, it agreed to the controls only because it expectcd country $A$ to do the same. 
as opposed to another will be relevant to a country's decision to violate the agreement in the first place. Indeed, in some cases the threat of such retaliation will be enough to prevent a violation. In many cases, however, the simple abrogation of the treaty will not be enough to prevent a violation and, more importantly, will not be an optimal sanction. For instance, imagine that Country A and Country B each expect to receive gains of 5 as a result of an environmental agreement, but neither is certain of the actual gain. Both countries consent to the deal in good faith, but after the agreement is signed, Country A learns that it actually faces a loss of 1 as a result, rather than a gain of 5 , while Country B stands to gain 5 from the agreement, as expected. If both countries honor the agreement, the total benefit is 4 ( 5 for Country B, -1 for Country A). If Country A violates its commitment, and Country B abrogates the treaty, the total gain is zero. Country A will nevertheless violate the agreement (assuming there is no sanction other than abrogation) precisely because it is better off without it. The threat of abrogation alone is insufficient to provide optimal deterrence because optimal deterrence would require that Country A face a sanction of 5 if it violates the agreement. Thus the mere withdrawal of benefits conferred by an agreement may be an inadequate sanction.

The inadequacy of withdrawal of one's own compliance may lead states to impose other sanctions intended to punish the offending state. For example, following the Persian Gulf War, an embargo on Iraqi oil was put in place. Punitive sanctions of this sort need not be directly related to the violation and can therefore more easily be tailored to resemble optimal sanctions. Thus, even though Iraq's actions were only indirectly related to its oil sales, the embargo represented an available and relatively powerful sanction.

There are two important problems with the imposition of this sort of penalty. First, without a dispute-settlement procedure, ${ }^{153}$ it is difficult to distinguish appropriate sanctions from inappropriate ones. While it is true that punitive sanctions have the potential to be used as optinal sanctions, they generally are not imposed by neutral third parties but unilaterally by injured states. There is, therefore, the risk that the sanctions will be excessive and will overdeter. Second, the imposition of these sanctions imposes costs on both sanctioned and sanctioning states. For instance, the embargo on Iraqi oil has certainly hurt Iraq, but it has also hurt countries participating in the embargo by reducing the number of potential suppliers of oil. Because imposing a sanction inflicts costs on a sanctioning country, the

Country B was willing to comply to have Country A change its behavior. Without Country A's compliance, it is in Country B's interest to ignore the terms of the agreement.

153. There are, of course, some dispute-settlement bodies in the international community, including the International Court of Justice and the dispute-settlement procedures available at the WTO. They are put to one side for the moment and discussed below. 
incentive to impose optimal sanctions is often weak, leading to penalties that may be too lenient.

Despite their shortcomings, punitive sanctions should not be dismissed too quickly, especially when compared to the alternative international mechanisms for compliance. In some situations it is possible to have such sanctions imposed and, as a result, to provide more efficient incentives to states.

Consider first a one-shot game in which Country A violates international law and Country B must decide whether or not to expend resources punishing Country A. Assuming that the punishment is the last play of the game, Country B has no incentive to impose the punishment. Country A realizes this, so it is not deterred from violating its obligations. ${ }^{154}$ In a oneshot game, therefore, countries will not impose sanctions on other countries when doing so is costly. It is elementary game theory that the same result holds for any finitely repeated game. ${ }^{155}$ The situation changes, however, in an infinitely repeated game. Where states interact repeatedly over time, it may be worthwhile for states to develop reputations for punishing offenders. By punishing offenders today, states increase the likelihood of compliance tomorrow because the threat of future punishment is credible. To sustain such an equilibrium by using punishment, it must be worthwhile for a state to punish today's violation in order to achieve future compliance. This condition will be met when (1) the states have relatively low discount rates; (2) the cost to the punishing state is not too large relative to the benefit received when other states follow the law; and (3) the benefits from violations of the law are not too large relative to the payoff from following the law.

\section{When Will Sanctions Work Best?}

Recognizing the incentive effects of a direct sanction allows us to understand when sanctions are most likely to be imposed and work in an optimal manner. This Section addresses two dimensions along which the effectiveness of a sanction-whether direct, reputational, or both-is likely to vary: (1) bilateral versus multilateral sanctions, and (2) sanctions in ongoing versus short-term relationships.

\section{Bilateral vs. Multilateral Sanctions}

Within a bilateral relationship, sanctions signal a willingness to punish illegal conduct. Because many of the factors that determine a country's willingness to impose a sanction, including the relative power of the two

154. Note how different this case is from the withdrawal of benefits conferred, discussed above. If it is costly for Country B to honor its obligations to Country A, it will stop doing so once it becomes clear that country A has not kept its own promises.

155. See RASMUSEN, supra note 77 , at 88 . 
countries, the frequency of their interactions, and the general state of relations between the states, are slow to change in a bilateral relationship, a reputation for punishing violations is valuable, relatively easy to establish, and relatively easy to maintain. It is valuable because it yields benefits in a wide range of interactions. Such a reputation is easy to establish and maintain because the sanctioning party enjoys the full benefits of the sanction in the form of greater compliance by the would-be violator. It is, therefore, more likely to be worth the cost of establishing such a reputation. These factors make sanctions a relatively attractive strategy in a bilateral relationship.

The use of sanctions is much more difficult in the multilateral context. Faced with a violation, all countries have an incentive to free ride on the sanctioning efforts of others. A country that imposes a sanction gains only a portion of the benefits from that act. Other nonsanctioning members of the group also benefit. Since all countries have an incentive to free ride, one would expect too little use of sanctions in a multilateral environment. This may explain why international sanctions are often considered ineffective.

The lesson here is that it is difficult to achieve effective multilateral sanctions. Notice that the distinction between bilateral and multilateral sanctions turns on the nature of the sanction, not the nature of the underlying obligation. It is not a question of whether the entire relationship is bilateral or multilateral. Rather, it is a question of whether the punitive sanction is imposed bilaterally or multilaterally. If, for example, a country regularly sanctions any violation of a multilateral agreement-regardless of who suffers the harm-it is a multilateral situation. If, on the other hand, a country sanctions only violations that impact itself, that is a form of bilateral sanction. Multilateral agreements and organizations should note the problems with multilateral sanctions and tailor their dispute resolution and enforcement mechanisms accordingly. For example, dispute settlement within the WTO relies on rules permitting an offended party to sanction a violating state when other attempts to resolve the dispute have failed. This is a more sensible strategy than one in which all member countries are asked to impose a sanction even when only one country is injured. ${ }^{156}$

\section{Complex, Ongoing Relationships vs. Simple, Short-Term Relationships}

The role of reputation implies that international law is more powerful in complex, multifaceted relationships than in simple, one-dimensional

156. The WTO provides a dispute-settlement mechanism under which, if all else fails, a complaining party may impose sanctions on a party found to have violated its WTO obligations. Final Act Embodying the Results of the Uruguay Round of Multilateral Trade Negotiations, Apr. 15, 1994, Annex 2 art. 22, Legal INSTRUMENTS-RESULTS OF THE URUGUAY ROUND vol. 31, 33 I.L.M. 1126 (1994) [hereinafter Dispute Settlement Understanding]. 
ones. In a complex, ongoing relationship, individual interactions between countries are normally of modest value compared to the accumulated reputational capital and goodwill that exists. ${ }^{157}$ Examples of such ongoing bilateral relationships include those between Canada and the United States, France and Germany, and the United States and Japan.

When states interact in many different ways, a reputational loss to one of those countries can be more costly than it would be in a one-time interaction. ${ }^{158}$ It may be something of a fiction to imagine a one-time interaction among states in the modern world. For expositional purposes, however, it is convenient to assume that states can have such a relationship. The point that emerges from the analysis is not limited to simple one-shot interactions versus complex ongoing ones. The more complex a relationship, and the more the parties expect a close relationship in the future, the greater the effect of international law. ${ }^{159}$

As shown in Figure A, and the accompanying discussion, ${ }^{160}$ international law cannot affect a country's behavior in a one-shot game because the violation of international law presents no consequences. Specifically, violations do not affect the states' future interactions. Precisely the opposite is true in the case of complex, ongoing relationships between countries, where a blow to a country's reputation will inpact many future interactions and increase the cost of violating the law. Because any individual interaction is of limited value relative to the entire relationship, a country has a strong incentive to honor its commitments in such relationships even without an explicit sanction. Actions that have a positive impact on a country's payoff in a single interaction, but that harm the overall relationship, are often unattractive because the future costs outweigh the one-time benefit. ${ }^{161}$

Countries engaged in ongoing interactions and facing a high cost for violations of international law have a great deal to gain from a system in which they are able to select from a menu of commitment levels. ${ }^{162}$ By

157. Cf. Simmons, supra note 2, at 325 ("[T] here is suggestive evidence that the more a polity has invested in such a reputation, the less willing a government will be to tarnish its reputation through non-compliance ....").

158. See Downs \& Jones, supra note 134.

159. Even states with complex bilateral relationships violate their agreements with one another, of course, and the theory presented in this Article does not predict perfect compliance. The model merely predicts that such violations will be less common, all else equal, in a complex, ongoing bilateral relationship than in simple or multilateral relationships.

160. See supra pp. 20-21.

161. This conclusion must be qualified slightly because the reputational loss from a single violation may be less severe in a relationship with many interactions. That is, states in a complex bilateral relationship may already have definite views about the other state's willingness to comply with international law. Because reputations have been formed over many, many interactions, a single violation may have only a small impact. Nevertheless, a complex relationship increases the value of developing and maintaining a reputation for compliance because the benefits from such a reputation can be felt in all the different facets of the relationship.

162. For a discussion of varying compliance levels, see supra Part ll.E. 
adjusting their level of commitment, states are able to signal their willingness to honor their promises and can control the amount of reputational capital they stake as collateral. This flexibility allows states that enjoy a high level of mutual trust to enter into agreements that come with only low levels of commitment. Without the ability to modulate the level of reputational capital pledged, states would sometimes choose to make no deal at all rather than accept an obligation that they may not keep.

Finally, an ongoing relationship obviously has an important influence on the usefulness of punitive sanctions. As already discussed, there is no incentive to apply such sanctions in a one-shot or finitely repeated game. The more the relationship between two countries resembles a one-shot or short-term interaction, the less likely it is that punitive sanctions will be effective or useful.

\section{Acceptance of Sanctions}

States that violate an international obligation can, under certain conditions, be induced to accept a sanction voluntarily. If states are willing to submit to a penalty, it is possible to make the sanction much more effective. Rather than simply imposing a reputational sanction plus whatever direct sanctions are available, the punishment can be tailored to the precise violation. The beneflts of such a system include the opportunity to resolve disputes through arbitration or some other form of dispute resolution, a lower cost to complaining states than is the case with retaliatory sanctions, the ability to adopt optimal sanctions, and the potential to choose sanctions that are less disruptive to the international community.

A state will submit to punishment when the costs of that punishment are exceeded by the costs of a failure to accept the punishment. Thus, for example, countries that have signed a BIT are typically willing to submit to arbitration to resolve disputes with investors because a failure to do so may lead to a cancellation of the relevant BIT (and perhaps other BITs) and such cancellation would be more costly than the sanction imposed by the dispute-settlement process. ${ }^{163}$ Within the WTO, a state that violates its obligations is expected to voluntarily bring its conduct into conformity with WTO obligations. ${ }^{164}$ If it fails to do so, the parties to the dispute are to negotiate an appropriate compensation for the injured party. ${ }^{165}$ Finally, if these efforts fail, the injured party can seek authority from the dispute settlement body to impose retaliatory measures. The offending party is expected to accept the imposition of these measures. ${ }^{166}$ Similarly, within the

163. Even if no BIT is cancelled, a failure to honor the dispute-settlement obligation under a BIT will harm the country's efforts to attract new investment.

164. Dispute Settlement Understanding, supra note 156, art. 19.

165. Id., art. 22.

166. Id., arts. 21-22. 
European Union, states that lose decisions before the European Court of Justice comply with those rulings partly because a failure to do so imposes too great a risk for the success of the European Union and the place of the country within the Union. ${ }^{167}$

More generally, a country is likely to accept established procedures for dealing with violations of international law when it faces a severe sanction, such as expulsion from a treaty or organization, for a failure to accept punishment; when the consequences of a failure to accept punishment impose large costs on the country, such as actions that risk tearing down the European Union; and when a failure to accept punishment imposes large reputational costs, such as a reputation for ignoring established disputeresolution procedures. ${ }^{168}$

If states submit disputes to some form of dispute resolution and agree to abide by the sanctions that are handed down, it becomes possible to construct a more effective and efficient set of rules. In particular, it is possible to specify sanctions that are consistent with sound contract principles, the most prominent of which is expectation damages. ${ }^{169}$ If countries accept sanctions handed down by a dispute-settlement procedure, a system of expectation damages can be established within the international legal system. As in the domestic context, this will lead to breach if and only if breach is efficient. ${ }^{170}$

\section{IV \\ RETHINKING INTERNATIONAL LAW}

Up to this point, this Article has focused on developing a more complete theory of compliance with international law. This Part uses the

167. The notion that states may comply with international law because they do not want to undermine the international legal system has been advanced by Professor Trimble. A country "may decide to forgo the short-term advantages derived from violating those rules because it has an overriding interest in maintaining the overall system." Phillip R. Trimble, International Law, World Order and Critical Legal Studies, 42 STAN. L. Rev. 811, 833 (1990). The claim in this Article is more modest. It is merely asserted that within an organization-especially one that is still being formedindividual states that value the organization may comply with the rules of that institution even when doing so imposes some short-term costs.

168. See Lipson, supra note 123, at 506.

169. The actual identification of appropriate damages for any given offense will be difficult because it is hard to determine the value of damages caused by violations of international law.

170. It should be noted that reputation may interfere with the theory of efficient breach in the international context. To the extent that a country that violates an international commitment and subsequently submits to the relevant dispute-settlement process nevertheless suffers a loss of reputation, expectation damages would overdeter, causing too little violation of international law. On the other hand, a regime in which a violating state fully compensates other states for a breach may reduce the role of reputation. When states agree to a commitment, the reliability of one's counterparty is less important if it is known that the counterparty can be sanctioned for a violation. The provision of expectation damages implies that the party who suffers from a violation of international law will do no worse in the event of a violation than if the law were complied with. For this reason, that state need not concern itself with the reputation of other states. 
theory to take a fresh look at the traditional sources of international law: treaties and CIL. It argues that the current approach to "soft law" must be changed. It then demonstrates that many of the topics upon which international law has focused the most attention are precisely the areas where international law is least likely to influence state behavior. This Part closes by exploring the implications of this conclusion, including the need to redirect some of the energies and resources of both states and international law scholars.

\section{A. Rethinking Treaties}

The most formal and reliable international commitment is a treaty. ${ }^{171}$ Aside from signaling a high level of commitment by a state, treaties offer several advantages to states: (1) treaties represent clear and well-defined obligations of states; (2) treaties can provide for explicit dispute resolution; ${ }^{172}$ and (3) treaties define rules for accession to and exit from their terms. ${ }^{173}$ In addition, third parties can observe their content with relative ease. Treaties can also provide for sanctions, the most obvious of which are the ability of complying states to cancel the treaty if it is violated, the potential for a sanction imposed by the treaty itself, and the reputational impact of violations. States agree to an elevated level of commitment in a treaty to obtain an elevated level of commitment from others. ${ }^{174} \mathrm{~A}$ treaty, therefore, should be viewed as a contractual commitment by a group of states. Using treaties, states can increase one another's reputational stakes and thereby increase the costs of breach. ${ }^{175}$

Within traditional international law, all treaties are considered equivalent in the sense that they are all binding. ${ }^{176}$ Nevertheless, they are sometimes violated. A major failing of traditional accounts of international law is their inability to explain such violations. When viewed through the lens of the reputational model presented in this Article, it is clear that not all treaties have the same impact on national incentives or the same chance of influencing a country's behavior. Without a theory of compliance, it is impossible to consider the circumstances under which violations take place or to develop strategies to improve the compliance pull of a treaty.

171. Treaties are also the focus of most theories of compliance with international law. See Koh, supra note 3; Oscar Schachter, Towards a Theory of International Obligation, 8 VA. J. INT'L L. 300, 301 (1968).

172. See, e.g., NAFTA, supra note 92.

173. There are various other costs and benefits involved in treaties that are not directly relevant to the question of how treaties impact behavior. These include, for example, the fact that treaties often take longer to negotiate than less formal agreements and the fact that they must be approved by signatory governments (which may increase the chances that the treaty will be honored because it increases the level of domestic support and may entrench the agreement in domestic laws).

174. See Guzman, supra note 104.

175. See Lipson, supra note 123 , at 508.

176. See Vienna Convention on the Law of Treaties, supra note 33, art. 18. 
At least two dimensions are critical to an understanding of treaty compliance. The first is the reputational impact of a violation, which has already been discussed. The second dimension is the cost of compliance, which is informed by the subject matter of the treaty. Treaties that implicate critical issues of national security and other issues of central importance to states are less likely to succeed in tipping the scales in favor of compliance. These treaties implicate issues of profound national importance, and it is unlikely that reputation will be enough to change a country's course of action from violation to compliance. ${ }^{177}$ In other words, the decision of whether to act in accordance with the treaty will most likely be made based on costs and benefits that have nothing to do with international law. ${ }^{178}$

\section{B. Rethinking Customary International Law}

CIL is the second form of international law recognized by traditional scholars. Unlike treaties, however, CIL is not the product of explicit bargaining and formal ratification. Under the traditional interpretation, it arises instead from widespread state practice and opinio juris-a sense of legal obligation. ${ }^{179}$ The theory advanced in this Article suggests that the standard understanding of CIL needs to be rethought. This Section outlines some of the changes that should be made in how CIL is understood.

Most international law scholars acknowledge that our understanding of CIL suffers from a variety of well-known problems. ${ }^{180}$ First, there is no agreement on how widespread a custom must be in order to satisfy the state practice requirement; indeed, there is not even a consensus on what counts as state practice. Among the instruments that are sometimes considered evidence of state practice are treaties (both bilateral and multilateral), national laws, and governmental statements of policy. ${ }^{181}$ The required duration of the state practice is similarly difficult to pin down. Related to the question of duration is the question of continuity. It is difficult to know if a single act, inconsistent with the practice, is enough to undermine that practice. If it is not, there is no agreement on how much discontinuity is enough. Second, the opinio juris requirement fares no better as a theoretical matter than does the state practice requirement. Professor D'Amato refers to the circularity of opinio juris as its "fatal defect": "How can Custom create law if its psychological component requires action in conscious

177. See infra Part IV.D.

178. One can certainly imagine cases in which the decision to honor or violate a military treaty is such a close one that the reputational consequences will make a difference. The more important the issues at stake, however, the less likely it is that such a case will come about.

179. See Anthony D'Amato, The Concept of Custom in International Law 6-10 (1971).

180. Id.

181. Id. 
accordance with preexisting law?"182 The lack of a sound theoretical foundation for CIL makes it difficult to identify how CIL coines into being and how it changes over time. ${ }^{183}$ Furthermore, violations of $\mathrm{CIL}$ are difficult to identify because the rules themselves are often vague. Without some formal legal instrument to define the obligation, the scope of the law is hard to know. And even when violations take place and are unambiguous, they can sometimes be justified through the use of the "persistent objector" exception to CIL. ${ }^{184}$

The problems with $\mathrm{CIL}$ have led many to question whether it exists at all as a relevant force in international law. ${ }^{185}$ Among the recent critics of $\mathrm{CIL}$ are Professors Goldsmith and Posner, who have advanced what is essentially the realist model presented in Part II. $\mathrm{A}^{186}$ and concluded that $\mathrm{CIL}$ is irrelevant to state behavior. ${ }^{187}$ They recognize the potential for reputation to affect coinpliance, but express deep skepticism about its role, ${ }^{188}$ suggesting that other doinestic interests truinp reputational concerns. ${ }^{189}$ At their most controversial, Goldsinith and Posner assert that " $[t]$ he faulty premise is that CIL-either the traditional or the new-influences national behavior." 190 When they claim CIL is irrelevant to national conduct, however, they go beyond what either the theory or the evidence suggests. As the general theory advanced in this Article suggests, CIL may influence state

182. Id. at 66 .

183. See BYERS, supra note 7, at 180-83.

184. See IAN Brownlie, Principles of Public International LaW 512-15 (4th ed. 1990). But see Jonathan I. Chamey, Universal International Law, 87 AM. J. INT'L L. 529, 538-39 (1993) (arguing that the persistent-objector rule is rarely used and may not be effective in practice).

185. See, e.g., Boyle, supra note 53, at 198 ("International law is therefore irrelevant to those matters which count the most, or more forcefully, to those matters which count for anything in international relations.").

186. See Goldsmith \& Posner, supra note 5; Jack L. Goldsmith \& Eric A. Posner, Understanding the Resemblance between Modern and Traditional Customary International Law, 40 VA. J. INT'L L. 639 (2000) [hereinafter Goldsmith \& Posner, Understanding].

187. See Goldsmith \& Posner, Understanding, supra note 186, at 640,641 ("CIL as an independent normative force has little if any impact on national behavior ...."). In earlier writing, they are less forceful in their claims, stating that " $\mathrm{CIL}$ has real content, but it is much less robust than traditional scholars think, and it operates in a different fashion." Goldsmith \& Posner, supra note 5, at 1177.

188. See Goldsmith \& Posner, supra note 5, at 1135 ("[I]t is hard to see why reputation would play an inportant role in explaining coinpliance with CIL norms beyond the limited sense in which it describes tit-for-tat and related strategies in the repeat bilateral prisoner's dilemma.").

189. "[I]t is hard to see why reputation would play an important role in explaining compliance...." Id. This view of reputational arguments fails to consider that reputation, like any enforcement mechanisin, operates at the margins. Other national objectives reinain relevant and may trump reputation even if reputation exerts soine compliance pull. Goldsmith and Posner seem to agree, stating "[o]ne might conclude that all things equal, nations will strive to have a reputation for compliance with international law, but a reputation for compliance will not always be of paramount concern because all things are not equal." Id. at 1136 . This statement is essentially the same as this Article's observation that reputation is relevant to decision-making.

190. Goldsmith \& Posner, Understanding, supra note 186, at 640. 
behavior through both reputational and direct sanctions. ${ }^{191}$ Even if direct sanctions are weak - as they surely are with respect to ClL-reputational sanctions may be enough to generate compliance.

An alternative interpretation of CIL, one that addresses the theoretical difficulties with the traditional approach without denying the existence of CIL, is suggested by the theory advanced in this Article. Under this theory, CIL represents a form of legal obligation that countries have toward one another, even without explicit agreement. That much is consistent with the traditional view of legal scholars. A reputational model also addresses CIL's critics and resolves the theoretical problems with the traditional definition. Indeed, under this view, the problems of CIL are not problems at all. Rather, they are factors that either cause CIL to be a weak form of commitment or represent the product of that weakness. For example, the ambiguity regarding the content of CIL makes it a relatively weak mechanism through which to pledge reputational collateral. Because CIL's content is uncertain, states can often claim to have complied even when they have ignored the content of CIL. In other words, the commitment to CIL is more easily avoided than the commitment to a treaty. Like a contract that can be revoked at any time, an international commitment that can be avoided has limited force. To demonstrate that even the limited force of CIL can matter, however, consider the example of diplomatic immunity. The immunity of diplomats from the jurisdiction of local courts was a longstanding principle of $\mathrm{CIL},{ }^{192}$ and was widely, though not universally, respected. One would expect this in a reputational model because the cost of providing diplomatic immunity is normally small when compared with the reputational cost of violating it.

The above discussion suggests a new definition of CIL: CIL consists of legal norms whose violation will harm a country's reputation as a lawabiding state. ${ }^{193}$ Compare this definition to the traditional one. The practice requirement, present in traditional accounts of CIL, is not an explicit factor under a reputational account of international law. The practice requirement becomes important indirectly, however, if it causes a particular norm to be seen as an obligation.

Unlike the traditional concept of opinio juris, what matters under the theory advanced in this Article is that countries other than the offending state believe that there is such an obligation. That is, a state faces a norm of CIL if other states believe that the state has such an obligation and if those other states will view a failure to honor that obligation as a violation. Only

191. For a critique of Goldsmith and Posner and a detailed discussion of why ClL can exist within a rational choice framework, see Edward T. Swaine, Rational Custom, forthcoming, Duke L.J. (2002).

192. See Ian Brownlie, Principles of Public International Law 345-59 (3d ed. 1979).

193. Notice that under this new definition, it no longer makes sense to ask whether or not ClL affects state behavior-it does so by definition. Instead, one can ask whether ClL exists. 
under these circumstances will a violation by the state lead to a reputational loss. If, for example, respect for the principles of diplomatic immunity is considered a legal obligation, then a violation of those rules will be viewed by other states (or perhaps only the offended state) in a negative light. This will cause those states to doubt the reliability of the offending state, making them less prone to trust it in the future.

The good news for traditional international law scholars is that this Article offers a theoretical model that is consistent with the existence of $\mathrm{CIL}$. The bad news is that the model does not predict that CIL represents a powerful legal constraint. Problems of clarity and a lack of explicit commitment on the part of states make CIL weaker than treaties. CIL looks even less potent when one remembers that reputational constraints have limited power, even under ideal circumstances. Thus, while it is true that the existence of $\mathrm{CIL}$ is consistent with the theory presented here, the actual impact of $\mathrm{CIL}$ on decisions is an empirical question, the answer to which is left for future research. Although I do not agree with the claim of Professors Goldsmith and Posner when they assert that CIL does not matter, I believe that it is a weak force on international law and may affect outcomes only infrequently. ${ }^{194}$ If reputation plays a small enough role, simply ignoring it and adopting a realist model may be appropriate.

Unfortunately, we simply do not know how much reputational capital is at stake with respect to $\mathrm{CIL}$. It is clear that $\mathrm{CIL}$ is weaker than treaties in part because $\mathrm{CIL}$ is typically not clearly specified, making its boundaries ambiguous. There is often debate about whether a particular norm of CIL exists at all, and countries normally have not consented to $\mathrm{CIL}$ in an explicit way, making their commitment to it uncertain. For all of these reasons, the possibility that $\mathrm{CIL}$ is so weak as to be negligible cannot be dismissed until some form of empirical evidence becomes available. ${ }^{195}$

194. To the extent that the theory advanced by Professors Goldsmith and Posner is extended beyond CIL to treaties or other agreements, my disagreement with their theoretical claims becomes more vigorous.

195. GoIdsmith and Posner offer some case studies of CIL in support of their theory. See Goldsmith \& Posner, supra note 5, at 1139-67. This evidence suffers from the usual problems with case studies. First, without observing how countries would behave in the absence of CIL, it is difficult to draw conclusions about how they actually behaved. For example, violations of the three-mile territorial sea rule that existed during the nineteenth and early twentieth centuries cannot be cited as examples of the failure of CIL unless one knows that no states were ever affected by the rule. It is impossible to determine if there would have been more violations in the absence of a rule of ClL. Second, periodic violation of international law is consistent with the reputational model advanced herein and should be consistent with any sensible model of compliance. As a result, pointing to incidents of a failure to comply does not distinguish one theory from another. Finally, to support the realist position that CIL has no effect, one must provide more than evidence that it is sometimes ignored. Rather, one must show that it is always ignored and that state behavior is never changed by CIL-a task that simply cannot be accomplished through case studies. On the other hand, even a single example in which CIL can be shown to influence behavior would be sufficient to disprove the realist theory. 
Regardless of the empirical importance of CIL as a category, the reputational model provides a more satisfactory framework within which to view CIL than does the realist model. Under a realist model, one must either treat all international law as irrelevant-a position that is, to my knowledge, not advocated by any legal scholar-or treat CIL as different in kind from other forms of international obligation. The latter option leads to an awkward framework in which each form of international obligation is explained through a separate theory, making it difficult to consider the many different forms of obligation together. The realist theory also fails to explain behavior in those circumstances in which CIL does seem to matter, such as diplomatic immunity. The reputational model, on the other hand, views the many different forms of international agreement as points on a spectrum. CIL is perhaps the weakest form of international law, but it is nevertheless part of the general framework. As the level of state commitment increases, the reputational stake is raised and the commitment becomes more credible. This theory explains not only CIL, but all forms of international commitment. It also explains why nations choose one form of commitment over others and why states expend resources in order to comply, or appear to comply, with their commitments.

\section{Rethinking International Law}

The previous Section proposed a new definition of CIL that turns on the question of whether a state is perceived, by other states, to have a legal obligation and whether a failure to live up to that obligation harms the state's reputation. This Section proposes a broadening of the definition of international law to more explicitly include obligations that are neither treaties nor CIL.

In domestic law, it makes sense to use the term "law" to distinguish obligations that are legally enforceable from those that are not. When using "law" in the international context, however, analogies to domestic contract law are difficult. In particular, it makes no sense to restrict the use of "law" to obligations that are legally enforceable because most international legal obligations exist without any sort of formal enforcement mechanism. The associated conclusion that very little of international law qualifies as law, however, does nothing to help us understand the operation of international law. A vocabulary is needed to distinguish those obligations of states that affect incentives and behavior, and the term law seems to be sufficient for that purpose. 


\section{Soft Law}

The classical usage of "international law" refers only to treaties and CIL. ${ }^{196}$ This definition excludes promises made by states through instruments that fall short of full-scale treaties, such as memoranda of understanding, executive agreements, nonbinding treaties, joint declarations, final communiqués, agreements pursuant to legislation, and so on. The place of such commitments, sometimes referred to as "soft law," within the framework of international law is uncertain. ${ }^{197}$ What is clear is that traditional international law scholarship considers soft law less "law" than the "hard law" of treaties and custom. The focus of international legal scholars is often exclusively on treaties and custom, as if soft law either does not exist or has no impact. ${ }^{198}$ Although only occasionally stated explicitly, the general presumption appears to be that soft law is less binding than the traditional sources of international law, and states are accordingly less likely to comply. ${ }^{199}$

Confusion over the role of soft law is due in part to the fact that discussions of compliance have largely failed to address the question. ${ }^{200}$ As a

196. Strictly speaking, the most traditional definition of international law also includes "general principles of law recognized by civilized nations" and "judicial decisions and the teachings of the most highly qualified publicists of the various nations, as a subsidiary means for the determination of rules of law." See Statute of the Intemational Court of Justice, supra note 9, art. 38(1)(c)-(d).

197. For more about "soft law," see Tadeusz Gruchalla-Wesierski, A Framework for Understanding "Soft Law", 30 McGiLl L.J. 37 (1984); Gunther F. Handl et al., A Hard Look at Soft Law, 82 AM. SoC'Y INT'L L. PRoc. 371 (1988); K.C. Wellens \& G.M. Borchardt, Soft Law in European Community Law, 14 EUR. L. REv. 267 (1989). The term "soft law" is used herein to denote law that falls short of the classical definition of intemational law. See Raustiala, supra note 126, at $\div 7$ (describing "soft law"). This is a common usage of the term, but it is not the only one. Some use the term to describe rules that meet the classical definition but that are imprecise or weak. See Prosper Weil, Towards Relative Normativity in International Law, 77 AM. J. INT'L L. 413, 414 n.7 (1983) ("It would seem better to reserve the term 'soft law' for rules that are imprecise and not really compelling, since sublegal obligations are neither 'soft law' nor 'hard law': they are simply not law at all.").

198. See Steven R. Ratner, Does International Law Matter in Preventing Ethnic Conflict?, 32 N.Y.U. J. INT'L L. \& PoL. 591, 652 (2000).

199. F. van Dijk, Normative Force and Effectiveness of International Norms, 30 GRRMAN Y.B. INT'L L. 9, 20 (1987). Perhaps the most traditional position views agreements other than treaties as nothing more than evidence of custom. See Pierre-Marie Dupuy, Soft Law and the International Law of the Environment, 12 Mich. J. INT'L L. 420, 432 (1991). Under another view, soft law "tends to blur the line between the law and the nonlaw, be that because merely aspirational norms are accorded legal status, albeit of a secondary nature; be that because the intended effect of its usage may be to undermine the status of established legal norms." Handl et al., supra note 197, at 371; Richard H. Steinberg, In the Shadow of Law or Power? Consensus-Based Bargaining in the GATT/WTO, 56 INT"L ORG. 339, 340 (2002) ("Most public intemational lawyers, realist, and positivists consider soft law to be inconsequential."). But see, Kenneth W. Abbott \& Duncan Snidal, Hard and Soft Law in International Governance, 54 INT'L ORG. 421 (2000) (arguing that soft law can be effective).

200. Ratner, supra note 198, at 654. But see INTERNational Compliance with Nonbinding Accords (Edith Brown Weiss ed., 1997); Commtment and Compliance: The Role of NonBinding NoRMS IN THE INTERnational LeGal System (Dinah Shelton ed., 2000) (analyzing "soft law" in environment and natural resources, trade and finance, human rights, and multilateral arms control). 
result, soft law remains largely outside the theoretical framework of international legal scholars. ${ }^{201}$ This is a curious fact because many instruments that are not considered "law" under the classical definition have a substantial impact on the behavior of states. ${ }^{202}$ If the term "law" is used to identify promises that are particularly difficult to break, there is nothing to distinguish treaties and CIL from soft law. The latter should also be considered forms of international law. ${ }^{203}$

Like treaties, nonbinding agreements benefit from a high degree of clarity and are often drafted by specialists with deep technical knowledge. Because these agreements are not treaties, they are often relatively easy to change and can be concluded more quickly and with less attention. Unlike treaties, however, they do not represent a complete pledge of a nation's reputational capital. The agreements are made with an understanding that they represent a level of commitment that falls below that of a treaty. The violation of such an agreement, therefore, carries a less severe reputational penalty than does the violation of a treaty.

That said, a failure to honor the terms of such an agreement is not costless. The reputational costs imposed on violations of nonbinding agreements can take two forms. First, there is the reputational loss to the country itself. A state that routinely ignores promises that fall short of treaties will find that it cannot extract concessions in exchange for such promises. Second, an additional reputational cost is present when the agreement in question is negotiated and agreed to by government ministers or other agents of the state. If their countries do not honor the commitments, these individuals will be handicapped in their future attempts to enter into such agreements. For example, the Basle Accord was negotiated and agreed to by the central bankers of twelve countries. ${ }^{204}$ Although the Basle Accord is not a treaty and, as a result, is not considered binding under traditional definitions of international law, a central banker whose country failed to supervise banking activity in a manner consistent with the Basle Accord would surely face a loss of influence in the international regulation of banking and find it more difficult to enter into future negotiations. The individual government officials making the promises, therefore, have an incentive not to promise too much and to encourage their government to

201. Handl et al., supra note 199, at 372 .

202. "A wide variety of instruments, declarations, joint statements, and expressions, loosely categorized as 'soft law,' are accepted and enforced as constraints by processes that differ little from those applicable to formal legal undertakings." ChAYEs \& CHAYEs, supra note 4, at 2; Handl et al., supra note 199 , at 372.

203. Lipson, supra note 123 , at 502.

204. The countries are Belgium, Canada, France, Germany, Italy, Japan, Luxembourg, the Netherlands, Sweden, Switzerland, the United Kingdom, and the United States. See Duncan E. Alford, Basle Committee Minimum Standards: International Regulatory Response to the Failure of BCCI, 26 GEo. WASH. J. 1NT'L L. \& ECON. 241, 241 n.1 (1992). 
honor promises that are made. Failure to do so will lead to a reduction in international influence for both themselves and their countries. ${ }^{205}$

One can hardly doubt the important role that these agreements play in the coordination of international activity. The Basle Accord demonstrates how these agreements can change state behavior. The Accord was adopted in 1988 and provided for a transition period that ended in $1992 .{ }^{206}$ By 1992 , most international banks in major industrial countries were in compliance. ${ }^{207}$ Japan, in particular, made significant changes to its capital adequacy rules. ${ }^{208}$

Indeed, the reputational cost of a failure to honor the Basle Accord could easily extend beyond the banking arena. To the extent that such action is perceived to be a signal that a country does not take the promises of its negotiators seriously in the absence of a formal international legal commitment, such action could undermine all efforts to negotiate nonbinding agreements.

\section{A Functional Definition of International Law}

Under the theory advanced in this Article, the difference between the traditional sources of international law and those promises made by states that have not been viewed as "law" is one of degree. Agreements among states lie on a spectrum of commitment. The same reputational issues influence such promises regardless of the form in which they are made, but the magnitude of the reputational effect varies with the level of commitment.

This theory makes the traditional separation of treaties from soft law difficult to maintain because the theory recognizes no clear distinction between treaties and other promises. The classical formulation seems even more problematic when one considers $\mathrm{CL}$. The reputational capital at stake with respect to many rules of $\mathrm{CIL}$ is almost certainly less than what is at stake with some soft law agreements, such as the Basle Accord. The classical definition of international law, therefore, identifies the relatively powerful instrument of treaties and the relatively weak instrument of CIL,

205. It should be noted that agreements that fall short of treaties and that are negotiated by government agents are often implemented by the same agents who negotiated them. For example, the Basle Accord was negotiated by central-bank governors and bank supervisors. These same individuals and their institutions had the authority to bring domestic regulations into compliance with the Basle Accord. This is an additional reason why, as a practical matter, these agreements are able to influence the behavior of states.

206. See Joyce M. Hansen et al., Capital Regulation and Supervision of International Banking Organizations, in 1 Regulation of Foreign BanKS : UNITED STATES AND INTERNational $\S 4.01$, at 175-76 (Michael Gruson \& Ralph Reisner eds., 3d. ed. 2000).

207. See Hal S. Scott \& Philip A. Wellons, International finance: Transactions, PoLICY \& REgulation (5th ed. 1998).

208. In 1986, Japan had a ratio of tangible equity to total assets of $1.9 \%$. In 1992, four years after the Basle Accord came into being, that ratio was $3.42 \%$. 
but does not recognize obligations whose force often lies between these two extremes. In other words, tension exists between the classical theory of international law and its practice.

Reconciling theory and practice requires a new theoretical approach, based on a revised definition of international law. It should be one that is functional rather than doctrinal. Rather than simply listing what is and is not considered international law, the new definition should describe the characteristics of international law. Instruments that fit that definition should then be considered international law.

The central question of interest in this Article is whether the practice of making an international commitment alters the behavior of countries. It is tempting, therefore, to define international law in an outcome-based fashion by applying the label of international law to those international obligations that change behavior and denying it to obligations that do not. A definition of this sort, however, ignores the fact that laws-even domestic laws - can only alter the incentives of actors. The law itself cannot determine outcomes. For example, a law against speeding is no less a law when people speed. It is a law because it increases the expected cost of speeding.

A definition of international law that turns on changed outcomes is also problematic because an international commitment may be respected in one context but not in another. Imagine, for example, a state's commitment to honor certain territorial boundaries between itself and its two neighbors. The state may choose to violate the agreed-upon boundary between itself and one neighbor but refrain from violating the boundary with its other neighbor. A definition that turns on outcomes would have to label the commitment "international law" with respect to one neighbor but not the other. In fact, until the moment at which a country decides whether or not to honor the commitment, it would be impossible to determine whether there was an applicable international law at all. In other words, "international law" would be reduced to a synonym for honoring commitments.

The defimition of international law, therefore, should turn on the impact of a promise on national incentives. With that in mind, this Article defines international law as those promises and obligations that make it materially more likely that a state will behave in a manner consistent with those promises and obligations than would otherwise be the case. In some instances this change in incentives will affect outcomes. In other cases, however, it will not.

The proposed functional definition of international law reflects the fact that international obligation comes in many different forms, with varying levels of compliance pull. This is a significant departure from the conventional view of international law, which simply declares law to be binding. The new theory recognizes that the discrete categories of treaties, 
CIL, and soft law, though perhaps useful, do not themselves define international law or represent the only possible levels of commitment. Rather, they are attempts to describe the spectrum of commitment from which states choose the level that suits their purposes at any given time.

\section{The Problem of Large Stakes}

All else equal, it is reasonable to expect that the compliance pull of international law will be the weakest when the stakes at issue are large. This is so because reputational effects have limited power. The likelihood that reputational effects will be sufficient to ensure compliance grows smaller as the stakes grow larger. Consider, for example, the decision to use military force against another state. Both the costs and benefits from such an action are typically very large. ${ }^{209}$ Because the stakes are so high, a country is unlikely to take an action that is otherwise contrary to its interests in order to preserve its reputation. The value of a reputation for compliance with international commitments is rarely large enough to affect the outcome when decisions are of such great magnitude..$^{210}$

Imagine, for example, that a country must decide whether or not to invade a neighbor's territory in violation of international law. Invasion promises to provide benefits in the form of greater territory, resources, and a reduction in the strategic threat from that neighbor. Label these benefits $B .^{211}$ The cost of entering into the war includes loss of life, economic costs, social costs, and so on. Label these costs $C$. In addition, a decision to go to war would bring about a reputational loss in the international community. Label this cost $R$. The reputational consequences of going to war will only affect the decision if $0<B-C<R$. That is, reputational effects will prevent a war only if the country would otherwise have gone to war, but the decision to do so was sufficiently close that the reputational cost tips the balance in favor of peace. When the costs and benefits of a particular action are small, there is a good chance that the reputational consequences will tip the balance in favor of compliance with international law. Where the costs

209. By this I mean that the costs of going to war-including human, economic, political, and social costs-are large, and a country will only choose to go to war if it has strong reasons that represent large benefits.

210. Formally, it is not merely the magnitudes of the costs and benefits that matter, but also the state's discount rate at the time. The reputational cost of a violation of international law is felt over time. It is the loss of future agreements, opportunities, or goodwill that hurts a country when it compromises its reputation. In order to evaluate such costs, a decision-maker must account for the fact that they are in the future. That is, the present discounted value of those benefits must be calculated. The discount rate that is applied to future losses will depend on the circumstances. In times of war, for example, a country will weigh the present much more heavily than the future because there is no guarantee that the state will continue to exist in its present form.

211. To represent the risk that the war will be lost, B can be thought of as the benefits of war multiplied by the probability of victory. 
and benefits other than reputation are relatively large, however, it is less likely that reputational costs will be enough to alter the outcome.

The above discussion implicitly assumes that the reputational cost of violating an international obligation is fixed. Under this assumption, international law has less effect as the stakes get larger. Although convenient to demonstrate that the most important issues are less likely to be affected by international law, the assumption of a constant reputational cost for violations of such law is unrealistic. ${ }^{212}$ That being said, it remains true that reputation plays a more important role when the costs and benefits of a particular action are small. This is so for at least two reasons. First, there is an upper bound to the reputational cost that a country can suffer as a result of a decision. Even a complete loss of reputation has a limited cost for a country. Furthermore, a single decision to violate international law is unlikely to cause a complete loss of reputational capital. Faced with a matter of great importance, therefore, even the most severe reputational sanction is unlikely to affect state behavior.

Second, although the reputational cost of a violation of international law can vary based on the circumstances, it does not necessarily increase with the importance of the issue. For example, a country's decision to violate an arms control agreement may impose reputational costs only in the area of arms control. Other states may recognize that military and national security issues are central to a country's identity and that treaties in that area are not particularly reliable. ${ }^{213}$ As a result, the violation of this sort of treaty may not call into question the willingness of the state to honor a treaty in another area, such as economic matters. Remember that violations of international law impose a reputational cost because they have a negative impact on other countries' perception of a state's willingness to accept short-term costs in order to protect long-term relationships and trust. When compliance with international law would impose extreme losses on a country, violation of that law may not have much impact on reputation. Such a violation sheds little light on the willingness of a state to violate agreements when the costs of compliance are smaller. This helps to explain why analysis of the role of international law during the Cold War leads to a pessimistic set of conclusions-many issues were perceived to involve high stakes. $^{214}$

212. See Lipson, supra note 123, at 509 ("Not all violations discredit equally.") (footnote omitted).

213. See Richard Baxter, International Law in "Her Infinite Variety", 29 INT'L \& CoMP. L.Q. 551 (1980). Baxter stated that treaties that declare alliances, establish neutral territories, or announce broad policy guidelines are "merely joint statements of policy which will remain alive only so long as the States concerned see it to be in their mutual interest to concert their policies. One simply cannot think of 'violations' of such instruments." Id.

214. See Kal Raustiala \& Anne-Marie Slaughter, International Law, International Relations and Compliance, in HandbooK of InTERnational Relations 28 (W. Carlnaes et al. eds.). 
These implications are significant for the study of international law. Most obviously, the theory predicts that international law will have the smallest impact in those areas of greatest importance to countries. This observation suggests that many of the inost central topics in traditional international law scholarship are the most resistant to influence. Thus, for example, the laws of war, territorial limits (including territorial seas), neutrality, arms agreements, and military alliances are among the areas least likely to be affected by international law. Although agreements with large stakes can be stable, this will rarely be the result of the obligations imposed by international law. Adherence to such agreements is more likely to be the result of a game in which international law plays no more than a small part. The existence of an international legal obligation may be consistent with the outcome, but it is unlikely to alter behavior.

The mcssage for scholars is twofold. First, international law scholars may be focusing their efforts in the wrong place. Rather than concentrating on those topics that are of greatest importance to states, they might do better to devote more attention to those areas in which international law can yield the greatest benefits. The most promising fields of study, therefore, are those in which reputational effects are likely to affect behavior. Some international law scholars may be disheartened by this message. After all, international law is an interesting subject in part because it concerns itself with great questions of war, peace, alliances, human rights, and so on. ${ }^{215} \mathrm{~A}$ focus on more mundane questions might seem to diminish the grandeur of the field of study. On the other hand, there is also an optimistic side to this conclusion. International law is often criticized for being irrelevant. By turning the attention of scholars to areas in which international law matters most, the importance of the subject can be demonstrated. Furthermore, those areas in which international law matters are themselves of great importance. These include, for example, the entire range of international economic issues, from trade to the international regulation of competition law to environmental regulation. The livelihood and sometimes the lives of millions of people depend on the effective resolution of international economic issues. Surely this is a worthwhile subject for international law scholars.

This discussion is not intended to imply that international law scholars must or should completely abandon the field when it comes to the sort of large-stakes questions that have occupied so much of the discipline in the past. Scholars have a role to play in important international agreements because they are uniquely qualified to evaluate the structure of the related institutions and the manner in which agreements are struck. International

215. See, e.g., Ratner, supra note 198, at 593 ("The ability of international law to make a difference in ethnic disputes also goes to the heart of contemporary debates about the pertinence of international law to state decision-making."). 
law can be used to strengthen national commitments, but its value depends on the context. Scholars must focus not only on the legality of state actions, but also on the ways in which international law can be structured to improve compliance. Issues involving large stakes can sometimes be influenced by international law, but this is most likely to be achieved through an indirect use of international commitments. For example, an agreement not to develop nuclear weapons is, by itself, unlikely to have much relevance. If it is combined with obligations with stakes that are lower but that cumulatively achieve the desired goal, success is more likely. For example, if it is possible to monitor compliance through regular inspections, countries will be less likely to violate their obligations. Monitoring allows violations to be detected early, which both reduces the benefits of violation-a nuclear weapons program that is detected early provides fewer benefits to the violating state-and increases the costs - early detection might cause other countries to withdraw their own promises, denying the violating country the benefit of compliance by others. The point here is that scholars should approach large-stakes issues with compliance in mind, and they should be searching for institutions and agreements that achieve the desired objectives through a series of discrete, low-stakes compliance decisions rather than through a single large-stakes decision.

Second, there is a message for critics of international law. Following the lead of international law scholars, critics point to the failure of international law in areas where it is unrealistic to expect success. Because they use the easiest cases to criticize international law, their attacks on the subject are unpersuasive. These attacks should be aimed at those areas in which international law plays a larger role.

\section{CONCLUSION}

This Article hopes to achieve several goals. First, it lays out a theory of international law and compliance that explains how national behavior is influenced by international law. It does so within the framework of a rational actor model in which states value a reputation for compliance with international obligations. Along with the possibility of direct sanctions, reputation provides an incentive for states to comply with their obligations. By developing and preserving a good reputation, states are able to extract greater concessions for future promises.

Because the magnitude of reputational sanctions is limited, the Article points out that they will not always provide sufficient incentive for nations to comply with the law. This explains why one sees violations of international law in some instances. It also suggests that scholars of international law should keep the limits of that law in mind. In particular, it is unlikely that international law can influence decisions of fundamental importance to the state with any frequency. Where individual decisions have a more 
modest impact, however - a situation that arises frequently in, for example, the world of international economic and regulatory cooperationinternational law may be able to alter outcomes more frequently.

The Article also offers a new definition of CIL. The theoretical problems with CIL stem from the commitment of legal scholars to the traditional definition that emphasizes jus cogens and opinio juris. A more useful definition turns on the extent to which other states believe that a country has a legal obligation and the extent to which that country's reputation is harmed by a failure to honor that obligation.

Taken seriously, a reputational model of compliance leads to important changes in the way we view international law. It forces us to reject the classical definition of international law, which considers only treaties and $\mathrm{CIL}$ to be law. Instead, it leads us to a more functional definition, which considers any international promise or commitment that has a substantial influence on national incentives to be law. It also forces us to recoguize in an explicit way that not all international law is created equal. Some obligations are more binding than others, and states choose the level of their commitments against this background fact. We can no longer be satisfied with the simple conclusion that "treaties are to be obeyed."216

Above all, the theory advanced in this Article offers a more realistic and compelling model of international law-one in which both instances of conipliance and instances of violation can be understood, in which the full spectrum of agreements negotiated by states is explained, and in which the role of international law can be understood within a model of selfinterested states.

216. See supra note 33 and accompanying text. 
